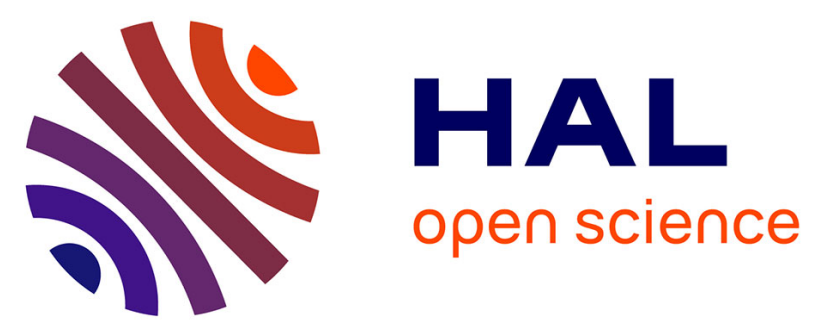

\title{
Analogue modeling of large-transport thrust faults in evaporites-floored basins: Example of the Chazuta Thrust in the Huallaga Basin, Peru
}

Sandra Borderie, Bruno Vendeville, Fabien Graveleau, César Witt, Pierre Dubois, Patrice Baby, Ysabel Calderon

\section{To cite this version:}

Sandra Borderie, Bruno Vendeville, Fabien Graveleau, César Witt, Pierre Dubois, et al.. Analogue modeling of large-transport thrust faults in evaporites-floored basins: Example of the Chazuta Thrust in the Huallaga Basin, Peru. Journal of Structural Geology, 2019, 123, pp.1-17. 10.1016/j.jsg.2019.03.002 . hal-02536870

\section{HAL Id: hal-02536870 \\ https://hal.science/hal-02536870}

Submitted on 22 Oct 2021

HAL is a multi-disciplinary open access archive for the deposit and dissemination of scientific research documents, whether they are published or not. The documents may come from teaching and research institutions in France or abroad, or from public or private research centers.
L'archive ouverte pluridisciplinaire HAL, est destinée au dépôt et à la diffusion de documents scientifiques de niveau recherche, publiés ou non, émanant des établissements d'enseignement et de recherche français ou étrangers, des laboratoires publics ou privés.

\section{(c) (1) $\$$}

Distributed under a Creative Commons Attribution - NonCommerciall 4.0 International 


\section{Analogue modeling of large-transport thrust faults in}

2 evaporites-floored basins: example of the Chazuta Thrust in

3 the Huallaga Basin, Peru.

4 Sandra BORDERIEa,1, ${ }^{*}$, Bruno C. VENDEVILLEa, Fabien GRAVELEAUa, César WITTa, Pierre

5 DUBOIS ${ }^{a, 2}$, Patrice BABYb ${ }^{b}$ and Ysabel CALDERON ${ }^{c}$

$6{ }^{*}$ Corresponding author: University of Fribourg, Department of Geosciences, Chemin du

7 Musée 6, 1700 Fribourg, Switzerland -sandra.borderie@unifr.ch_-004126300 8934

8 a Univ. Lille, CNRS, Univ. Littoral Côte d'Opale, UMR CNRS 8187, LOG, Laboratoire

9 d'Océanologie et de Géosciences, F 59000 Lille, France. bruno.vendeville@univ-lille.fr

10 fabien.graveleau@univ-lille.fr cesar.witt@univ-lille.fr_duboispierre11@gmail.com

11 b Géosciences Environnement Toulouse (GET), Université de Toulouse, CNRS UMR 5563 /

12 UR 234 IRD / UPS Toulouse / CNES, 14 Avenue Edouard Belin, 31400 Toulouse, France.

13 patrice.baby@ird.fr

14 c PERUPETRO S.A., Avenida Luis Aldana n³20, San Borja, Lima 41, Peru.

15 ycalderon@perupetro.com.pe

Keywords

Huallaga Basin; Chazuta Thrust; evaporitic décollement; analogue modeling; strain

localization; surface processes

\footnotetext{
${ }^{1}$ Present address: University of Fribourg, Department of Geosciences, Chemin du Musée 6, 1700 Fribourg, Switzerland.

${ }^{2}$ Present address: Perenco - Oil and Gas, 8 Hanover Square, London W1S 1HQ, England.
} 


\section{Abstract}

The Huallaga Basin is a deformed foreland basin located in North Peru. The basin comprises several syntectonic depocenters. The most significant is the Biabo Syncline located at the back of the Chazuta Thrust, a long, flat-floored thrust detaching on an evaporitic décollement, which has accommodated more than $40 \mathrm{~km}$ of horizontal displacement. The hangingwall of the Chazuta Thrust has remained remarkably intact with little or no internal deformation and has incorporated a large volume of evaporites at its base.

In order to unravel the formation and evolution of this thrust, we conducted a series of physical experiments that tested the role of various parameters. The goal is to investigate a system in which most of the deformation is accommodated in the frontal part of the chain (Chazuta Thrust), whereas deformation of the thrust sheet itself remains minor.

Results from our experimental investigations suggest that the three key parameters that have allowed for such a long-lived, large-slip frontal thrust to operate are (1) the wedgeshaped syn-kinematic sedimentation, (2) the presence of the Biabo Syncline, which acted as a bulldozer pushing the evaporites forward, forcing their distal inflation and (3) the erosion at the front that favored farther advance of the frontal thrust, dragging passively large volumes of evaporites along with it.

\section{Introduction}

It has long been demonstrated that the dynamics of fold-and-thrust belts (FTBs) is notably controlled by the interaction between tectonic and climate surface processes (erosion and sedimentation) (e.g. Dahlen, 1990; Whipple, 2009; Willett et al., 1993). However, getting 
direct field evidence proving this has been challenging. Analogue and numerical modeling has greatly helped in better understanding the mechanisms by which both erosion and sedimentation can modify the mechanical equilibrium of such accretionary systems (see reviews by Buiter, 2012; Graveleau et al., 2012). Primarily, syntectonic sedimentation exerts a first-order control on the number and spacing of thrusts, with deposition of thicker, wedge-shaped sediments favoring the formation of longer, somewhat "rigid" thrust sheets (e.g. Bonnet et al., 2008; Fillon et al., 2013; Mugnier et al., 1997; Wu and McClay, 2011). By reducing the average slope of the wedge, sedimentation reduces thrust advance in the outer parts of the belt. In order to maintain the critical wedge, older structures have to be reactivated at the hinterland (Huiqi et al., 1992; Boyer, 1995; Storti and McClay, 1995; Simpson, 2006; Stockmal et al., 2007; Wu and McClay, 2011). Similarly, erosion prevents deformation from propagating toward the foreland and therefore reduces the length of the belts. It reduces the number of active thrusts and therefore increases their lifetime (Koyi et al., 2000; McClay and Whitehouse, 2004; Cruz et al., 2010).

The term overthrust faulting was first used by Hubbert and Rubey (1959) on the basis of a former definition by Billings (1954) to describe flat, spectacular allochthonous geological features along which large masses of rock have been displaced along great distances. Large transport thrust faults (i.e. displacement greater than $10 \mathrm{~km}$ ) have been reviewed using displacement-scale relationships (e.g. Bergen and Shaw, 2010; Kim and Sanderson, 2005). Some examples exist along the McConnell thrust in the Canadian Rockies (Elliott, 1976), the Glencoul thrust in the Moine thrust belt of Scotland (Coward et al., 1980), the Midi Thrust in the Ardennes massif of the Northern Europe Variscan belt (Lacquement et al., 1999), the Salt Range in Pakistan (Grelaud et al., 2002) and the Hotian Thrust in the Tarim Basin 
(Wang et al., 2014), among others. However, the mechanisms by which such long-transport thrusts form have been poorly addressed in the past by neither numerical nor analogue modeling techniques; although much progress has been made in determining the magnitude of fault and crustal strength (Suppe, 2007, 2014).

The main issue in reproducing long-transport thrust using analogue modeling is the great difficulty of accommodating most (if not all) the shortening along one single structure. In this work, we present a set of analogue models, where parameters such as syntectonic sedimentation, basal detachment tilting, pre-kinematic tabular sedimentary cover and erosion of the frontal structures have been tested, leading to different evolutionary scenarios. Our analogue modeling protocol is inspired from the current knowledge of the structural and sedimentary architecture of the Huallaga Basin in north Peru (Figure 1). This basin is part of the modern Andean retro-foreland basin system in which compressional structures are largely influenced by the presence of evaporites. For instance, the major Chazuta Thrust accommodates at least $40 \mathrm{~km}$ of horizontal transport (i.e. $~ 50 \%$ of shortening of the FTB, (Hermoza et al., 2005; Calderon et al., 2017a, 2017b), with very little strain within the allochthonous thrust sheet and a large volume of evaporites incorporated into the hangingwall.

\section{Geodynamic setting and structure of the Huallaga Basin}

The Andean FTB extends across more than $5000 \mathrm{~km}$, from Colombia and Venezuela in the North, to Patagonia and the Tierra del Fuego in the South. This is one of the most welldeveloped retro-arc, non-collisional FTB worldwide. Very diverse tectonic settings have 
occurred since the Paleozoic to the Present Day from compressional, extensional and strike-slip (e.g. Macellari and Hermoza, 2009; Ramos, 2010).

The Sub-Andean segment of Peru is part of the deformed retro-foreland basin system of the Andes and corresponds to one of the most segmented sections of the Andean FTB (Figure 1). It can be divided into four main deformed foreland basins having different geological configurations. From North to South these include the Santiago, Huallaga, Ucayali-Camisea and Madre de Dios Basins and related fold-and-thrust belts (Figure 1). From the Huallaga Basin to the Madre de Dios Basin the parameters controlling the style and amount of deformation, as well as the width of the FTB, change drastically (e.g. McGroder et al., 2015). Along-strike variations in FTB architecture have been ascribed to differences in basement composition, lithosphere rigidity, climate variations, ridge subduction, distance from the tectonic driving force, varying stress orientations relative to crustal fabrics, plate subduction regime, and differences in pre-deformational settings (e.g. Espurt et al., 2008; Gil Rodriguez et al., 2001; Kley et al., 1999; Macellari and Hermoza, 2009; McQuarrie et al., 2008; Ramos, 2010; Ramos and Folguera, 2009).

The Huallaga Basin corresponds to a wedge-top basin (Hermoza et al., 2005) according to the foreland model subdivision of DeCelles and Giles (1996). It is bounded to the West by the Eastern Cordillera and to the East by the Marañon basin. Its northern and southern limits are the Santiago Basin and the Ucayali Basin, respectively (Figures 1 and 2). Several balanced and restored cross sections in the central part of the basin show that deformation is the result of interaction between thin- and thick-skinned processes (Gil Rodriguez, 2001; Hermoza et al., 2005; Eude et al., 2015; Calderon et al., 2017b). Thin-skinned deformation is largely controlled by the presence of thick evaporitic series. Nevertheless, because of the 
few constraints obtained by seismic and well data, different models have been proposed to explain the contractional deformation of the Huallaga Basin. They include inversion of Permo-Triassic grabens (e.g. Hermoza et al., 2005) and reactivation of Permian, basementrelated thrusts verging towards the hinterland (Eude et al., 2015; Calderon et al., 2017a, 2017b). In their structural interpretation (Figure 3), Calderon et al. (2017b) infer there was a reactivation of west-verging basement thrusts inherited from a Permian fold-and-thrust belt under the Huallaga Basin. These authors also reinterpreted the chronostratigraphy of the area, suggesting that evaporites of the Huallaga Basin are late Permian in age and belong to the Shinai Formation (Figure 3). Thermochronological data and sequential restoration indicate that deformation began between 30 and 24 Ma to the East of the Eastern Cordillera by the reactivation of the basement faults and the formation of thrusts that root into the evaporitic décollement (Eude et al., 2015). This is in agreement with the work of Hermoza et al. (2005), which states that a foredeep depozone was present in the Huallaga basin at that time.

In map view, the basin geometry has an arcuate shape (Figure 2). In the central part of the basin, the structures are parallel to each other and strike orthogonally with respect to the direction of shortening. In contrast, in the northern and southern parts of the basin, the structures are oblique with respect to the shortening direction. This basin has a detachment-related salient geometry controlled by the presence of an evaporitic décollement that acts as a regional detachment and modifies the along-strike contractional structures (Macedo and Marshak, 1999).

We used three seismic sections to interpret and illustrate the geometry of the Huallaga Basin. Their location is indicated on the morphostructural map in Figure 2. The basin 
shows a vertically and horizontally compartmentalized structuration. The shallow part of the basin is characterized by the Chazuta Thrust that corresponds to a fault-bend fold rooting at depth into the late Permian evaporitic décollement, and accommodates a large horizontal displacement (at least $40 \mathrm{~km}$, Figures 2, 3 and 4). In the eastern part of the basin, major thrust systems (e.g. Chazuta and Shanusi Thrusts) mark the deformation front. The upper-frontal part of these thrusts has been eroded, and Cretaceous rocks crop out there. Erosion is marked by truncated reflectors on the seismic profiles (Figures 4 and 5). The western part of the basin is characterized by the Biabo Syncline, presently located on the hangingwall of the major Chazuta Thrust (Figures 3 to 6). The Biabo Syncline comprises a 6-7 km thick pile of Eocene-Pliocene syn-tectonic sediments (Hermoza et al., 2005). The Biabo Anticline is a fault-propagation fold that offsets the Neogene series (Figures 3 and 6). Apatite fission-track analyses along the Chazuta system yielded cooling ages of approximately $16 \mathrm{Ma}$, which are interpreted to be caused by thrust-related uplift (Eude et al., 2015).

The Chazuta thrust sheet is almost non-deformed in the center of the basin (Figures 2, 3 and 4) but its northern and southern parts shows a series of thrusts and backthrusts that deformed the hangingwall, although only minor slip is accommodated along each fault (Figures 2, 5 and 6). Another feature well illustrated on the seismic profiles is that a large volume of evaporites moved up along with the thrust sheet, remaining part of the hangingwall. These evaporites are therefore placed in an allochthonous position (Figures 3, 4 and 5), a feature rarely seen in contractional evaporites-related FTB (Costa and Vendeville, 2002), but common in salt tongues in the US Gulf of Mexico (Amery, 1969; 
Worrall and Snelson, 1989; Wu et al., 1990b, 1990a; Nelson, 1991; Peel et al., 1995; Rowan, 1995).

The top of the Chazuta Thrust footwall is clearly imaged only on a couple of seismic sections (Figures 4 and 5) and was not reached by the only well drilled in the area (Posanillo Well: Figure 6, see location in Figure 2). In the footwall of the Chazuta Thrust, the décollement is thinner than in the hangingwall. It has an autochthonous position and created a series of salt pillows (Figures 4 and 5). There are doubts about the processes controlling deformation in the footwall because seismic imaging beneath the evaporites is poor. Most of footwall geometry constraints are indirectly inferred from restoration and balanced cross sections. In the sequential restoration by Calderon et al. (2017b, 2017a), the Biabo Anticline and the west-verging basement thrusts were poorly developed the time of middle Eocene. Then, thin- and thick-skinned deformation propagated simultaneously from late Miocene until Present Day. This brings some contrasted interpretations about whether thin- and thick-skinned deformation were simultaneous or diachronous. If the deformation was simultaneous in the hangingwall and footwall (Eude et al. 2015, Calderon et al. 2017b, 2017a), the presence of the thick décollement in the hangingwall of the Chazuta Thrust sheet could have successfully decoupled the deformation between the two blocks. Therefore, the component of deformation transmitted by the basement (thickskinned) deformation would have been absorbed entirely by the evaporitic décollement and squeezed between both blocks. On the contrary, a diachronic scenario of deformation may be based on the lack of deformation in the Chazuta Thrust sheet, suggesting that the Chazuta Thrust formed after basement deformation took place. 
The complexity of the basin geometry and the scarcity of seismic data make it difficult to understand which mechanism(s) have led to the current geometry and kinematics of the basin. Interpretation of seismic data is not sufficient to explain several aspects of the basin and especially why the transport of the Chazuta Thrust is so large with a mostly nondeformed hangingwall, a singularity at the scale of the Subandean zone and worldwide. The main goal of this manuscript is to understand the conditions that have allowed an overthrust to accommodate such a large quantity of horizontal displacement, and how such a large evaporitic volume was able to be carried along with it.

\section{Analogue modeling methodology}

\subsection{Material and scaling}

Our experimental approach focused on modeling a contractional tectonic wedge where shortening could be accommodated continuously along one major frontal thrust. Our models were of the pull-from-the-base type, as in Storti and McClay (1995). The base of the sedimentary sequence was made of a viscous décollement of silicone polymer (SGM36, manufactured by Dow Corning, UK), as in Costa and Vendeville (2004), Ferrer et al. (2014), Sellier et al. (2013) and Weijermars and Schmeling (1986), which is a transparent, highviscosity polydimethylsiloxane (PDMS) polymer. Within the range of strain rates used during the experiments ( $\left.2 \times 10^{-6} \mathrm{~s}^{-1}\right)$, PDMS behaves as a Newtonian fluid having a negligible yield strength (Weijermars and Schmeling, 1986). Under these conditions, this is a proper analogue for salt rock, or, in general, evaporites. The basal viscous décollement was overlain by a brittle sedimentary cover made of dry quartz sand (GA39 and NE34, both manufactured by Sibelco, France). GA39 sand was used to cover the viscous décollement because it has a finer grain size than that of the NE34 sand. GA39 sand has a density of 1.42 
g.cm-3, a mean grain size of $127 \mu \mathrm{m}$ and an internal frictional coefficient of about 0.69

200 (Klinkmüller et al., 2016). NE34 sand was used for the rest of the overburden. It has a density of 1.65 g.cm ${ }^{-3}$, a mean grain size of $220 \mu \mathrm{m}$ and an internal friction coefficient of about 0.6 (Table 1, Klinkmüller et al., 2016). Sand layers had different colors in order to image sedimentary layering and faults, but had similar rheological behavior. In addition, each layer interface was highlighted with a thin black marker.

Following the rules of scaling for tectonic experimental models (Hubbert, 1937; Ramberg, 1981), dry granular materials are good analogues for brittle sedimentary rocks in the upper continental crust because they obey a Mohr-Coulomb criterion of failure (Hubbert, 1951; Krantz, 1991; Schellart, 2000; Lohrmann et al., 2003). Their angle of internal friction is similar to natural rocks, and their cohesion can be, once scaled, considered to be negligible. Scaling rules impose that the model-to-nature ratio for stress (imposed by the ratio of the lithostatic pressure), $\sigma^{*}$, should be:

$\sigma^{*}=\rho^{*} \times g^{*} \times L^{*}($ Equation 1$)$

where $\rho^{*}$ is the model-to-nature ratio for volumetric mass, $\mathrm{g}^{*}$ is the ratio for gravity acceleration and $L^{*}$ is the ratio for length. $L^{*}$ is set to $0.66 \times 10^{-5}$, which means that $1 \mathrm{~cm}$ in the model corresponds to $1.5 \mathrm{~km}$ in nature (Table 1). $\mathrm{g}^{*}$ is 1 because the models were deformed under a natural gravity field. The scaling ratio for density, $\rho^{*}$ is approximately 0.5 . We used a volumetric mass of $2.6 \mathrm{~g} / \mathrm{cm}^{3}$ for natural clastic rocks, $2.2 \mathrm{~g} / \mathrm{cm}^{3}$ for halite, 1.4 and $1.6 \mathrm{~g} / \mathrm{cm}^{3}$ for the sands we used, and $0.965 \mathrm{~g} / \mathrm{cm}^{3}$ for the silicone polymer (Weijermars et al., 1993; Santolaria et al., 2015). Considering these values, computed $\sigma^{*}$ is $3.33 \times 10^{-6}$. The cohesion value ranges of a few tens of Pascals for our granular materials, 
which would corresponds to a value for natural sedimentary rocks in the range of 10-30 MPa, which is in good agreement with the scaling rules (Schellart, 2000).

For scaling viscosity and time, we took a dynamic viscosity for rocksalt of $5 \times 10^{18}$ Pa.s (e.g. van Keken et al., 1993). This viscosity value was assumed from previously published data and not measured in this study. Note that estimated values for viscosity of natural rocksalt varies from $10^{16}$ and $10^{19}$ Pa.s (Carter, 1976; van Keken et al., 1993). If one considers another natural dynamic viscosity, it would drastically change the scaled natural velocity. The dynamic viscosity of the polymer we used is $2.2 \times 10^{4}$ Pa.s (Rudolf et al., 2016). These values yield to a model-to-prototype ratio for viscosity $\eta^{*}$ of $4.4 \times 10^{-15}$. The strain rate ratio, $\mathcal{E}^{*}$, is linearly related to stress and viscosity ratios by the following equation:

$\sigma^{*}=\eta^{*} \times \mathcal{E}^{*} \quad($ Equation 2$)$

Computing the strain rate yields to $\varepsilon^{*}=7.5 \times 10^{9}$, from which a model-to-nature time ratio can be quantified. As $\mathrm{t}^{*}=1 / \mathcal{E}^{*}=1.33 \times 10^{-9}$, which means that one hour in the experiment is equivalent to about 85000 years in nature. As our experiments lasted around 65 hours, this represents around 5.6 My of deformation time in nature. Finally, we applied a convergence velocity of $5 \mathrm{~mm} / \mathrm{h}$ in our model. This velocity, scaled to nature is:

$\mathrm{v}^{*}=\varepsilon^{*} \mathrm{x} \mathrm{L}^{*} \quad$ (Equation 3),

which corresponds to a velocity of about $9 \mathrm{~mm} / \mathrm{yr}$ in nature.

\subsection{Experimental setup and protocol}

We carried out seven experiments in a deformation device at the Tectonic Modeling Laboratory of the University of Lille, France. The box was $85.5 \mathrm{~cm}$ long and $60 \mathrm{~cm}$ wide and was bounded by two fixed glass sidewalls and by two fixed wooden end walls. The base of 
the deformation table was initially flat and covered by a linoleum sheet that was attached to a mobile wall attached to a screw jack controlled by a stepper motor (Figure 7). The basal linoleum sheet was able to move freely below the two fixed end-walls. Deformation was imposed by pulling the basal sheet at a constant velocity of $0.5 \mathrm{~cm} / \mathrm{h}$. In some experiments, the lateral friction along the glass sidewalls was decreased by lubricating them with a film of silicone polymer (as in Costa and Vendeville, 2002; Santolaria et al., 2015). This allowed reducing the influence of lateral friction during deformation. The evolution of deformation was recorded by two CCD cameras (Figure 7) that shot photographs every 30 minutes.

All models comprised a $60 \mathrm{~cm}$ wide, $65 \mathrm{~cm}$ long and $1.5 \mathrm{~cm}$ thick basal viscous décollement made of viscous silicone polymer (Figure 8), except for the first model (Chaz_01) that comprised a $1 \mathrm{~cm}$ thick polymer layer (Figure 8C, Table 2). The forelandwards edge of the polymer is called here pinch-out (Figure 8B and 8C).

In our protocol, we tested the role of several parameters on the geometry and evolution of deformation (Figure 8D, and Table 2). The tested parameters were mainly extracted from the restored cross section of Calderon et al. (2017b, Figure 3). There, we observed that the basal décollement is slightly tilted towards the foreland, and that the pre-tectonic sedimentary cover lays parallel to the décollement. We first tested the impact of the thickness of a tabular, pre-kinematic sedimentary cover (1.5 or $3 \mathrm{~cm}$ thick) and the tilting of an initially flat basement (Figure 8C). In some experiments, the pre-kinematic cover was completed by a sand wedge (Figure 8C, models Chaz_03 and 04). In the model Chaz_03 only, a sand wedge was deposited directly onto the basal décollement (Table 2). The idea for adding an overburden wedge onto the system came from the cross-section restoration 
of Calderon et al. (2017b) showing a thick Middle Eocene to Pliocene wedge at the rear of the Chazuta Thrust (yellow wedge in Figure 3). The presence of such wedge can alter the mechanical behavior and kinematic evolution of the evaporites and their overburden in two ways. First, the thickness of the brittle wedge decreases eastwards (towards the Chazuta thrust front), thereby decreasing its strength towards the foreland. Hence, it is the distal (thinnest) segment of the wedge that was most prone to fail first. As observed in other physical experiments, the proportionally thicker rear of the wedge did not deform (Smit et al., 2003). Second, deposition of a thick wedge on top of the evaporites would tend to cause the overburden to subside in the proximal region (rear part of the wedge), favoring forward evaporites flow and leading to evaporites inflation in the distal part (e.g.

Wu et al., 2014). In our study area, evaporites inflation towards the foreland uplifted the overburden, allowing the Chazuta Thrust to incorporate the evaporites in the advancing allochthonous sheet and favoring a longer slip. This would also explain how such large volumes of evaporites can be found in an allochthonous position within the Chazuta thrust sheet. We tested the influence of surface processes in our experimental protocol by adding variable syn-kinematic sedimentary wedges having different thicknesses and tapering towards the foreland (Figure 8D; models Chaz_04, 05, 06 and 07). The front of the Chazuta Thrust was also subjected to erosion as observed in the seismic sections where cretaceous rocks crop out at the front of the thrust. In order to evaluate the role of erosion we eroded the deformation front in models Chaz_06 and Chaz_ 07. Finally, an episode of pre-kinematic deformation was tested by creating artificially an analogue of the Biabo Syncline that formed earlier, and was located on the hinterland side of the Chazuta Thrust (models Chaz_06 and 07). In order to generate artificially a pre-kinematic syncline, we deposited a 
small, linear sand ridge (trending parallel to the décollement pinch-out) onto the overburden. Under the sole effect of gravity, the local excess weight forced this narrow area to subside and acquire the shape of a synform. As a result, a synform nearly grounded onto the base of the viscous décollement, as did the Biabo Syncline in our study area.

All the models were shortened up to about $31 \mathrm{~cm}$, which corresponds to $46.5 \mathrm{~km}$ in nature. In this study, we compare the results of seven models that illustrate the impact of the parameters mentioned above (alone or in combination) on the accommodation of the deformation along one major thrust. We then compare these mechanisms and parameters with the Chazuta Thrust in the Huallaga Basin.

\subsection{Strength profiles analysis}

The evolution of model deformation was recorded using top- and side-views photographs that allowed producing movies (see supplementary material) suitable for an accurate kinematical investigation. Analysis of strength profiles was also carried to quantify the bulk strength of models and to compare the experimental results. In previous works, Bonini (2001 and 2007) and Smit et al. (2003) discussed the effect on deformation style of relative

We first computed the vertical normal stress for the brittle overburden, which corresponds to $\sigma_{3}$ for compressional regime, using: 
311 where $\rho$ is the mean density of the sand, $g$ the acceleration of gravity, and $h$ the thickness of

312 the brittle overburden.

313 From the Mohr circle, we calculate the magnitude of $\sigma_{1}$ following :

$314 \sigma_{1}=\sigma_{3 \times}\left(1 \frac{2 \sin \phi}{(1-\sin \phi)}\right)$ (Equation 5),

315 where $\phi$ is the mean angle of internal friction for the material of the brittle overburden

316 (Table 1). We used the differential stress to quantify the strength of the brittle overburden,

317 computing $\sigma_{1-} \sigma_{3}$

318 Then, we computed the shear stress in the viscous layer $\left(\tau_{d}\right)$ to quantify the strength of the

319 viscous décollement, using :

$320 \tau_{d}=\eta \times \dot{\gamma}=\eta \times \frac{\mathrm{v}}{\mathrm{h}_{\mathrm{d}}}($ Equation 6$)$,

321 where $\eta$ is the viscosity of the silicone polymer (Table 1) and $\dot{\gamma}$ is the shear strain rate,

322 defined by the ratio between the backstop velocity $\mathrm{v}$ and the viscous décollement thickness

$323 \mathrm{~h}_{\mathrm{d}}$ (Table1). One can note from Eq. 6 that the shear stress in the décollement is an inverse

324 function of the thickness of the décollement. Therefore, for given backstop velocity and

325 décollement viscosity, the décollement becomes stronger when its thickness decreases.

326 We then computed the ratio between the differential stress in the brittle overburden and

327 the shear stress in the décollement $\left(R=\left(\sigma_{1}-\sigma_{3}\right) / \tau_{d}\right)$. This stress ratio defines the brittle328 ductile coupling (Allemand, 1988) and controls the distribution of deformation (distributed 329 vs. localized) and the deformation style. 
The evolution of deformation of each model is described based on its morphostructural evolution in map view. Side-view movies of each experiment are provided as supplementary material to this article. The final structure after shortening is illustrated in map view and by a cross section. Figure 8 and Table 2 indicate the parameters tested for each model.

The magnitudes of stress are reported in Table 3. The strength profiles representing the differential stress for the brittle overburden and the shear stress for the décollement with respect to depth are illustrated for each model in Figure 9.

\subsection{Model Chaz_01}

The first model, Chaz_01 had a flat, horizontal basement, a $1 \mathrm{~cm}$ thick, tabular layer of viscous silicone polymer, and a $1.5 \mathrm{~cm}$ thick, tabular pre-kinematic brittle sand overburden. The sidewalls were lubricated (Table 2 ). The stress ratio for $C_{h a z} 01\left(R_{\text {Chaz }_{-} 01}=173\right)$ is relatively small (Table 3, Figure 9).

Deformation nucleated at the décollement pinch-out $\left(\mathrm{T}_{1}\right)$, which acted as a major velocity discontinuity (Figure 9A). Subsequent thrusts and ( $T_{2}$, to $T_{6}$ ) nucleated at the rear of the first thrust, leading to an "out-of-sequence" deformation style (Figure 10A to 10E, Supplementary material 1). In this model, the $31 \mathrm{~cm}$ of shortening were accommodated by about six structures that partitioned the deformation. The majority of the thrusts were located at or near the front of the wedge (Figure 10), whereas the rear of the wedge was characterized by one detachment fold associated with a backthrust ( $\left.\mathrm{B}_{9}\right)$.

\subsection{Model Chaz_02}

In model Chaz_02, the thickness of the sand overburden was double of that in model Chaz_01 (from 1.5 to $3 \mathrm{~cm}$ ), and the décollement thickness was increased from 1 to $1.5 \mathrm{~cm}$ 
(Table 2), leading to a stress ratio three times higher $\left(\mathrm{R}_{\mathrm{Chaz}_{-} 02}=519\right)$ than for Chaz_01 (Table 3, Figure 9).

Deformation initiated at the distal foreland pinch-out of the décollement with the formation of a thrust and a backthrust $\left(\mathrm{T}_{1}\right.$ and $\mathrm{B}_{1}$, Figure $\left.11 \mathrm{~A}\right)$. Then, deformation along $\mathrm{B}_{1}$ stopped and two near thrusts $\left(\mathrm{T}_{2}\right.$ and $\left.\mathrm{T}_{3}\right)$ nucleated at the back of thrust $\mathrm{T}_{1}$ in an "out-of-sequence" mode (Figure $11 \mathrm{~A}$ to $11 \mathrm{~F}$, Supplementary material 2). At the end of the experiment, the wedge comprised three fault-related folds associated with thrusts located across the entire length of the wedge. As confirmed with the computation of the stress ratio, doubling the thickness of the sedimentary cover increased its strength, reducing the number of structures and increasing their wavelength (Figure 11G).

\subsection{Model Chaz_03}

In model Chaz_03, a sand wedge was deposited directly above an initially tabular viscous décollement layer before the onset of shortening. The deposition of the sand wedge was done after having tilted the base of the deformation box by 3 degrees (Table 2). Because of the deposition of the wedge, the initial stress ratio between the brittle overburden and the décollement varied across strike in this model (Figure 9). It was much smaller (by a factor of 7) at the wedge toe than near the backstop. In this experiment, the sidewalls were not lubricated to strengthen and test the frontal localization of deformation at the wedge toe.

Results indicate that the $31 \mathrm{~cm}$ of shortening were accommodated entirely along one single structure $\mathrm{T}_{1}$ that nucleated at the distal pinch-out of the viscous décollement (Figure 12, Supplementary material 3). The top of the viscous décollement in the distal area was uplifted to a level higher than that of the thrust ramp, allowing some amount of the silicone polymer to be dragged forward along the thrust sheet (Figure 12G). A few small sand 
blocks can be found embedded within the allochthonous polymer corresponding to overburden debris that formed superficially at the front of the thrust and became progressively overrun by the thrust sheet and its viscous sole. In this experiment, there was no erosion. In the center of the model, the segment of the frontal thrust located beyond the allochthonous viscous décollement eventually grounded to a halt, forcing the formation of a new backthrust $\left(\mathrm{B}_{1}\right)$ and hindering any further advance of the $\mathrm{T}_{1}$ thrust sheet (Figure $12 \mathrm{~F})$.

\subsection{Model Chaz_04}

The boundary conditions for model Chaz_04 comprised a pre-kinematic $3 \mathrm{~cm}$ thick overburden overlain by a frictional wedge (Figure 8D, 13A and Table 2). This entailed two markedly different strength profiles across strike in the model (Figure 9). As for model Chaz_03, the stress ratio is higher near the backstop where the brittle overburden is thick and it is lower at the pre-kinematic wedge toe where the brittle overburden is thinner. Note that the value of the stress ratio at the wedge in Chaz_04 $\left(\mathrm{R}_{\mathrm{Chaz}_{-} 04}=1057\right)$ is equal to the value of the stress ratio for Chaz_02 (Table 3).

Two syn-kinematic wedge-shaped units (the first one in blue, the second one in brown) were added during shortening (Figure 13B and 13E). As in the previous models, deformation initiated at the viscous décollement pinch-out by the formation of $\mathrm{T}_{1}$ (Figure 13A). After deposition of the first syn-kinematic wedge, $T_{2}$ nucleated out of sequence near the sand-wedge pinch-out (Figure 13B, Supplementary material 4). At the final stage, this model showed three structures located at or near the front of the built wedge: two major thrusts and one minor one (Figure 13F and 13G). Compared with model Chaz_02 (Figure 11), in which deformation occurred across the entire length of the wedge, deformation in 
the model Chaz_04 was restricted to the front of the wedge (Figure 13). These results indicate clearly that by increasing progressively the overburden thickness at the back of the model, this increased the stress ratio difference between the wedge front and its inner part, and therefore lead pre- and syn-kinematic sedimentation to contribute to localize all the deformation at the wedge toe. The toe of the wedge was thinner, hence easier to deform. In both cases (models Chaz_02 and Chaz_04), an imbricate thrust system verging towards the foreland formed, but the location and the geometry of the thrust system was clearly different.

\subsection{Model Chaz_05}

The model Chaz_05 tested both syn-kinematic sedimentation above a thin $(1.5 \mathrm{~cm}$ thick) pre-kinematic cover, and syn-kinematic tilting (by $3^{\circ}$ ) of the model's base (Table 2). This syn-kinematic tilt of the bow would correspond to a foreland flexure of the basin. In this experiment, the glass sidewalls were not lubricated. The value of the stress ratio is constant across strike and relatively low $\left(\mathrm{R}_{\mathrm{Chaz}_{-} 05}=529\right)$, compared to previous models (Table 3, Figure 9).

Deformation started with a compressional phase of a tabular overburden overlying a tabular viscous décollement. Deformation initiated first at the viscous décollement pinchout by the formation of a thrust $\mathrm{T}_{1}$ (Figure 14A). As deformation progressed, three later structures (a thrust $\mathrm{T}_{2}$ associated to a backthrust $\mathrm{B}_{1}$, and a thrust $\mathrm{T}_{3}$ ) formed at the back of $\mathrm{T}_{1}$ (Figure 14B). Then, the landward tilt of the basement and the onset of a flat-top synkinematic sedimentary wedge (orange in Figure 14G) sealed temporarily the former structures (thrusts $\mathrm{T}_{1}, \mathrm{~B}_{1}, \mathrm{~T}_{2}$ and $\mathrm{T}_{3}$ ) before that they were subsequently reactivated and accommodated the rest of the shortening. Two last thrusts (thrusts $\mathrm{T}_{4}$ and $\mathrm{T}_{5}$ ) formed in an 
"out-of-sequence" mode in the middle of the wedge during the last stages of shortening (Figure $14 \mathrm{D}$ to $14 \mathrm{~F}$, Supplementary material 5). The structural style at the end of the experiment is characterized by two major thrusts accommodating most of the shortening ( $\mathrm{T}_{1}$ and $\mathrm{T}_{3}$, Figure $14 \mathrm{~F}$ and $14 \mathrm{G}$ ), and by three second-order thrusts $\left(\mathrm{T}_{2}, \mathrm{~T}_{4}\right.$ and $\mathrm{T}_{5}$ ). Once again, syn-kinematic sedimentation helped to localize deformation at the front of the wedge.

\subsection{Model Chaz_06}

In the previous models, the boundary conditions favored the localization of deformation at the front of the wedge, but models having a pre-kinematic, tabular overburden ceased to deform along one major thrust after a while, and deformation was distributed across the models. With models Chaz_06 and Chaz_07, we tested the impact of the formation of an early syncline (simulating the Biabo syncline in the Huallaga Basin), and how its presence might have affected the thickening of the evaporites in the distal area, and consequently, favoring overthrusting of the overburden, but also of the evaporites themselves. These two models allowed computing two initial strength profiles across strike (Figure 9). The values of the stress ratios are the same for both models because we did not vary the initial thickness of the overburden and décollement. The smallest stress ratio corresponds to the one of Chaz_05.

Model Chaz_06 comprised a flat and $1.5 \mathrm{~cm}$ thick sedimentary cover that overlay a $1.5 \mathrm{~cm}$ thick viscous décollement (Table 2). A sand ridge was deposited at $28 \mathrm{~cm}$ from the internal backstop (Figure 15A). Compression started after an early subsidence of the ridge that created a synform. Deformation started at the distal viscous décollement pinch-out by the formation of thrust $\mathrm{T}_{1}$. Then, a minor backthrust $\mathrm{B}_{1}$ formed on the flank of the synform 
(Figure 15A). Deposition of the first syn-kinematic sand wedge (green in overhead views) sealed $B_{1}$ (Figure 15B). The two former structures $\left(T_{1}\right.$ and $\left.B_{1}\right)$ were then reactivated, and no new fault appeared (Figure 15B to 15D, Supplementary material 6). Deposition of the second syn-kinematic sand wedge (brown in overhead view), combined with an episode of erosion of the deformation front (by vacuuming the sand that had collapsed in front of the frontal thrust) inhibited the subsequent growth of backthrust $B_{1}$, fossilizing this structure (Figure 15E). The main frontal thrust $\mathrm{T}_{1}$ accommodated all the shortening, favoring the inflation of the distal viscous décollement and thus arching and lifting the overburden. The initial position of the early synform close to that of the décollement pinch-out led them to collide during the last stages of the experiment. During these last stages, the distal viscous décollement thickened, uplifted its overburden, creating an open toe. The viscous décollement reached the surface and spread locally onto the foreland's surface (Figure 15F). The system being locked, no more viscous décollement was able to inflate, and propagation of the frontal thrust was made less easy. Finally, this experiment indicates that the presence of an early syncline allowed for a thick volume of allochthonous viscous décollement to rise above the thrust ramp (Figure 15G).

\subsection{Model Chaz_07}

In order to constrain the role of a pre-kinematic syncline located farther away from the viscous décollement pinch-out, one last model (model Chaz_07, Figure 16) was carried out. This experiment had a configuration similar to that of the previous model (Chaz_06, Figure 15 and Table 2) except for the fact that the ridge was positioned further behind, at $18 \mathrm{~cm}$ from the internal backstop. At the onset of the experiment, the base of the model was totally flat and deformation started by a thrust $\left(\mathrm{T}_{1}\right)$ located at the viscous décollement 
pinch-out, then was followed by the formation of a minor thrust $\mathrm{T}_{2}$, located at the back of the ridge (Figure 16A). A third thrust $\mathrm{T}_{3}$ nucleated at the rear of $\mathrm{T}_{1}$, just before the episode of syn-kinematic sedimentation. It is incipient in Figure 15A. Subsequently, the base of the deformation box was tilted landward, and a thick sedimentary wedge was added (green) sealing $\mathrm{T}_{2}$ and $\mathrm{T}_{3}$ (Figure 16B, Supplementary material 7 ). Thrust $\mathrm{T}_{1}$ continued to accommodate shortening. Slip along $\mathrm{T}_{1}$ was favored by erosion of the deformation front during the whole shortening, helped by the fact that some viscous polymer was dragged above the ramp along with the thrust sheet (Figure 16B to 16F). The final cross section in this model shows that deformation was essentially accommodated at the front of the wedge along one single fault plane $\left(\mathrm{T}_{1}\right)$. Thrust $\mathrm{T}_{1}$ remained active during the whole compression and accommodated the major part of shortening (Figure 16G). The combined effect of wedge-shaped sedimentation, and the bulldozing effect produced by the presence of the early synform forced the viscous décollement to thicken distally and hence to move upward and forward along with the frontal thrust. The new location of the syncline enabled the forward "bulldozing" effect, uplifting more volume of the viscous décollement than in the Chaz_06 model. The combination of syn-kinematic erosion, sedimentation and the presence of an early syncline located in the back led to the formation of a wedge where only one major, long-lived thrust accommodated the entire shortening and brought some of the viscous décollement into the hangingwall.

\section{Discussion}

The goal of this study was to decipher which parameters may have had the most significant influence on favoring the remarkable characteristics of the Chazuta Thrust (Huallaga Basin, Peru), that has (1) a large amount of slip along one single frontal structure, (2) a 
surprisingly intact allochthonous sedimentary series showing little or no deformation, and (3) the emplacement of a large volume of initially autochthonous evaporites passively dragged upward in an allochthonous position along with the thrust sheet. In this section, we first discuss the impact of the tested parameters on the structure of fold-and-thrust belts. We then give the insights that our models provide to better understand the formation of the Chazuta Thrust.

\subsection{Impact of the initial sedimentary cover thickness}

The first group of models (Chaz_01 and Chaz_02) tested the influence of the thickness of a tabular pre-kinematic sedimentary cover on the structural style and evolution of a foldand-thrust belt. Between models Chaz_01 to Chaz_02, we doubled the thickness of this cover. Such thickening increased the cover strength and reduced the number of structures and their wavelength (compare Figure 10F with Figure 11G). This is in good agreement with already published works for frictional and frictional-viscous wedges (Huiqi et al., 1992; Marshak and Wilkerson, 1992; Smit et al., 2003; Storti et al., 2007). The sidewalls of the models being lubricated, this helped the structures to propagate rapidly across the whole length of the model up to the décollement pinch-out.

\subsection{Impact of pre-or syn-kinematic sedimentation and basal slope}

The second group of experiments comprised three models (Chaz_03, Chaz_04 and Chaz_05), that tested the impact of a sedimentary wedge, either pre-kinematic (Chaz_03 model) or syn-kinematic (Chaz_04 and Chaz_05 models, respectively), on the kinematics of the deformation front. These models also tested the effect of tilting the basal décollement of the wedge towards the hinterland on the deformation. 
Model Chaz_03, comprising a pre-kinematic wedge and a tilted basement, showed that only one structure accommodated the whole shortening. At the end of shortening, a new backthrust formed, preventing any further advance of the thrust sheet (Figure 12F). Had the distal front of the thrust sheet been subjected to erosion, the allochthonous décollement might have ended up cropping out, allowing for much more advance of the allochthonous system (Merle and Abidi, 1995). Additionally, the absence of sidewall lubrication also favored the localization of deformation along one single structure.

The other two models from this group (Chaz_04 and Chaz_05) tested a similar effect, but with the presence of a pre-existing, tabular overburden (corresponding to Late Jurassic to early Eocene in the study area). Results indicate also that syn-kinematic sedimentation increased the thickness at the back of the wedge, hence its strength. This helped localizing deformation at the front of the wedge because the overburden was thinner there and easier to deform (Figure 13G and Figure 13G).

In summary, this group of three experiments highlights that the presence of an overburden wedge with or without a basal slope favors a longer activity of the thrusts in the distal area, at or near the décollement pinch-out. In models having an initial tabular overburden under more difficult as the frontal thrust slipped forward. The overburden that had to be carried forward along the distal front became so thick so that the frontal thrust progressively became locked, forming a frontal buttress, and forcing new thrusts to nucleate landward. In 
allochthonous position (Figure 13G and Figure 14G). Therefore, it is not obvious that the top of the silicone layer was raised much above the thrust-ramp level.

\subsection{Influence of early deformation and syn-kinematic erosion-sedimentation}

In the previously discussed models, the boundary conditions favored the localization of deformation at the front of the wedge, but models having a pre-kinematic, tabular overburden ceased to deform along one major frontal thrust after a while. With this last set of models, we tested the impact of the presence of an early synform and how it might have favored the thickening of the viscous décollement in the distal area, and consequently, helping its overthrusting.

Although the Biabo Syncline located at the back of the Chazuta Thrust was present before the formation of the Chazuta Thrust (see Middle Eocene stage in Figure 3), our goal was not to model the causes of its formation, but rather to evaluate how its presence might have impacted on the evolution of the overall system, and particularly on the kinematics of deformation at the frontal salt pinch-out. Typically, during thin-skinned shortening above an evaporitic layer, anticlines rise, whereas synclines subside deeply within the evaporitic layer, often grounding onto the base of the evaporites (e.g. Costa and Vendeville, 2002; Cotton and Koyi, 2000). During ongoing shortening, the distal evaporites bulldozed by the grounded syncline are pushed forward and forced to thicken up to the point that their top exceeds the height of the frontal thrust ramp. When this occurs it makes it possible for the evaporites to spill forward onto the foreland, locally developing salt sheets, such can be observed in the Fars region in Iran (e.g. Hudec and Jackson, 2006).

In Chaz_06, the combination of wedge-shaped syn-kinematic sedimentation and the bulldozing effect created by the early syncline helped the viscous décollement to inflate and 
hence to be incorporated into the frontal thrust. However, the initial location of the early synform was too close to that of the décollement pinch-out. The anticline and the distal ramp eventually collided during shortening, locking the system and blocking any further propagation of the frontal thrust (Figure 15). With the model Chaz_07, we show that the combination of syn-kinematic erosion/sedimentation and the presence of an early syncline located farther away at the back of the model, led to the formation of a wedge where a longlived major thrust accommodated the major amount of the shortening, and incorporated some viscous décollement in its hangingwall (Figure 16).

\subsection{Strength profiles analysis}

The overall structural style (distributed vs. localized strain) of a fold-and-thrust belt detaching over a viscous décollement, depends on the relative strength between the brittle overburden and the viscous décollement (e.g. Allemand, 1988; Bonini, 2001; Smit et al., 2003). For instance, a viscous layer tends to deform internally with distributed strain. In contrast, a brittle overburden tends to undergo localized deformation along fault planes or shear zones, with little or no internal strain between the faults. Had the viscous layer been stronger than the brittle one, strain in both layers would have been widely distributed throughout the model, and many faults would have formed in the upper sand layer.

All the initial strength profiles of our models show the same trend (Figure 9). In every models, the differential stress of the brittle overburden is much larger than the shear stress of the décollement. This clearly indicates that the brittle overburden is overwhelmingly (by orders of magnitude) stronger than the décollement. Therefore, we can confidently state that during our experiments, the overall structural style and evolution are nearly entirely dictated by deformation of the brittle overburden, while the role of viscous décollement is 
merely to accommodate the displacements of the upper sand layer, which deforms along only few thrust.

The differential stress of the overburden is 87 to about 870 times bigger than the shear stress (Table 3) which explains differences in the localization of deformation. The relatively small initial stress ratio in Chaz_01 led to localize the deformation along more structures than in Chaz_02, which had a bigger initial stress ratio. This is in agreement with the results of Smit et al. (2003) who state that the structural style is controlled by the relative strength between the décollement and the cover. In the last models of our study, the values of initial stress ratios confirm that the distribution of deformation along the wedge is function of the strength in the brittle overburden. Increasing the strength at the back of the wedge allowed localizing deformation at the frontal part of the wedge.

\subsection{Insights for the Chazuta Thrust in the Huallaga Basin}

The cross section restored by Calderon et al. (2017b) shows that the Huallaga Basin had several distinctive characteristics worth investigating. We tested, using a series of analogue experiments, the impact of several parameters that are present in the Chazuta Thrust. We compared our results with this thrust's present-day and restored cross sections in order to better understand its geometry and kinematics. The Huallaga Basin presents a tabular prekinematic sedimentary cover (from late Permian to Paleocene) and thick Eocene to Neogene syntectonic series, especially in the Biabo Syncline (Figure 3).

Our models indicate that the presence of a syn-kinematic wedge above a tabular cover contributes to localize the deformation at the front of the wedge. However it is not sufficient to generate a long-lived thrust that incorporates a large volume of evaporites in its hangingwall, such as in the case of the Chazuta Thrust in the center part of the basin. In 
606

607

608

609

610

611

612

613

614

615

616

617

618

619

620

621

622

623

624

625

626

627

order to obtain such a peculiar geometry, experimental results show that the wedge needs a locally thicker syn-kinematic proximal series and erosion of the deformation front.

The cross sections in the last two experimental models (Chaz_06 and Chaz_07) can be compared with those across the Chazuta Thrust. In the models, the synform that formed by the early subsidence of the sand ridges contributed to push the viscous décollement above the front of the wedge. Particularly, in model Chaz_07, the combination of the early formation of a synform and erosion of the deformation front during shortening led to the formation of a thrust that accommodated the major part of shortening. We believe that comparable processes have happened in the Huallaga Basin with the Biabo Syncline that pushed the evaporites towards the frontal part of the belt. Erosion of the Chazuta deformation front, as indicated by truncated reflectors on the seismic lines (Figure 4) helped the Chazuta Thrust to accommodate very significant amounts of shortening with little or no deformation of the hangingwall.

In the northern and southern parts of the Huallaga Basin, the geometry of the Chazuta Thrust is slightly different compared to the center part of the basin. In the North, the thrust sheet is offset by a backthrust at the front of the Biabo Syncline and by minor thrusts that root in the allochtonous décollement (Figure 5). In the South, the Chazuta thrust sheet is deformed by a pop-up structure (Figure 6). Our set of analogue models did not intend to explain these lateral variations, but some hypothesis can be made about them. For instance, these variations could be explained by along-strike variation of evaporites distribution and/or facies (e.g. Bahroudi and Koyi, 2003). The northern and southern parts of the basin seem to correspond to the limit of the evaporites area. The deformation in these parts of 
the basin could also be impacted by edge effects along the adjacent areas that do not have an evaporitic décollement (e.g. Zhou et al., 2016; Borderie et al., 2018).

\section{Conclusions}

We carried out a series of analogue experiments in order to understand the major geological parameters that have controlled the geometry and kinematics of the Chazuta Thrust (Huallaga Basin, Peru). This thrust accommodates an important amount of shortening and incorporates in its hangingwall an unusual large volume of the evaporitic décollement material. We tested different parameters, such as the presence of a tabular overburden, a syn-kinematic sedimentary wedge whose frontal tip lay near the frontal thrust and erosion at the front of wedge. The basement slope at the base of the viscous décollement layer. We also investigated the role of an early formed synform located at the back of the frontal thrust were. The major results are the following.

(1) A system comprising a tabular viscous décollement and a tabular overburden cannot generate a large amount of slip along a frontal thrust because this thrust is quickly deactivated in favor of new thrusts forming at the back of it.

(2) Deposition of a pre- or syn-kinematic wedge of above the system helps nucleating thrusts at the frontal pinch-out of the viscous décollement. The presence of a sedimentary wedge favors a forward flow of the viscous décollement. This leads the décollement to thicken and to reach an elevation higher than that of the footwall ramp. The incorporation of some volume of viscous décollement within the allochthonous system is favored, and thereby the duration in activity of the frontal structure increases. 
(3) The presence or absence of a slope at the base of the viscous décollement does not appear to have any major impact on the activity of the frontal thrust.

(4) The formation of an early syncline whose base rests near or on the base of the viscous décollement enhances distal décollement inflation. The syncline pushes forward the distal décollement during its advance, forcing it to inflate. This allows for the emplacement of allochthonous viscous décollement incorporated to the thrust system.

(5) Finally, the role of frontal erosion seems to be another key parameter. Without it, the debris in front of the thrust tend to accumulate and eventually act as a buttress that would block its activity.

On the basis of our experimental results, we believe that it is the particular combination of most (if not all) of the above parameters that contributed to the exceptional longevity of the Chazuta Thrust, its little inner deformation in the central part of the system and its very large horizontal displacement.

\section{Acknowledgments}

This work has been carried out during Sandra Borderie's Ph.D. at the University of Lille, with funding from the French Ministry of Research. Figure 1 and 2 were drawn using the software package GMT (Wessel and Smith, 1991). HIS Markit is kindly thanked for Academic Licenses of the Kingdom software. The authors thank PERUPETRO for providing the seismic data and the IRD-PERUPETRO Research agreement to allow us working in Lima. Gonzalo Zamora and Oriol Ferre are kindly thanked for his constructive advices on a 
version.

\section{References}

674

675

676

677

678

679

680

681

682

683

684

685

686

687

688

689

690

691

692

693

694

695

696

697

698

699

700

Allemand, P., 1988. Approche expérimentale de la mécanique du rifting continental. Sciences de la Terre. Université Rennes 1.

Amery, G., 1969. Structure of Sigsbee scarp, Gulf of Mexico. AAPG Bulletin 53, 2480-2482.

Bahroudi, A., Koyi, H., 2003. Effect of spatial distribution of Hormuz salt on deformation style in the Zagros fold and thrust belt: an analogue modelling approach. Journal of the Geological Society 160, 719-733.

Bergen, K.J., Shaw, J.H., 2010. Displacement profiles and displacement-length scaling relationships of thrust faults constrained by seismic-reflection data. Geological Society of America Bulletin 122, 1209-1219.

Billings, M.P., 1954. Structural geology, 2d ed., New York, Prentice-Hall. ed.

Bonini, M., 2007. Deformation patterns and structural vergence in brittle-ductile thrust wedges: An additional analogue modelling perspective. Journal of Structural Geology 29, 141-158. https://doi.org/10.1016/j.jsg.2006.06.012

Bonini, M., 2001. Passive roof thrusting and forelandward fold propagation in scaled brittle-ductile physical models of thrust wedges. Journal of Geophysical Research: Solid Earth 106, 2291-2311.

Bonnet, C., Malavieille, J., Mosar, J., 2008. Surface processes versus kinematics of thrust belts: impact on rates of erosion, sedimentation, and exhumation-Insights from analogue models. Bulletin de La Société Géologique de France 179, 297-314.

Borderie, S., Graveleau, F., Witt, C., Vendeville, B.C., 2018. Impact of an interbedded viscous décollement on the structural and kinematic coupling in fold-and-thrust belts: Insights from analogue modeling. Tectonophysics 722, 118-137. https://doi.org/10.1016/j.tecto.2017.10.019

Boyer, S.E., 1995. Sedimentary basin taper as a factor controlling the geometry and advance of thrust belts. American Journal of Science 295, 1220-1254.

Buiter, S.J.H., 2012. A review of brittle compressional wedge models. Tectonophysics 530-531, 1-17. https://doi.org/10.1016/j.tecto.2011.12.018

Calderon, Y., Baby, P., Hurtado, C., Brusset, S., 2017a. Thrust tectonics in the Andean retro-foreland basin of northern Peru: Permian inheritances and petroleum implications. Marine and Petroleum Geology 82, 238-250. https://doi.org/10.1016/j.marpetgeo.2017.02.009

Calderon, Y., Vela, Y., Hurtado, C., Bolaños, R., Baby, P., Eude, A., Roddaz, M., Brusset, S., Calvès, G., 2017b. Petroleum Systems Restoration of the Huallaga-Marañon Andean Retroforeland Basin, Peru. AAPG Memoir 114, 95-116. https://doi.org/10.1306/13602026M1143702

Carter, N.L., 1976. Steady state flow of rocks. Reviews of Geophysics 14, 301-360.

Costa, E., Vendeville, B.C., 2004. Experimental insights on the geometry and kinematics of fold-andthrust belts above weak, viscous evaporitic décollement: reply to comments by Hemin Koyi and James Cotton. Journal of Structural Geology 26, 2139-2141. https://doi.org/10.1016/j.jsg.2004.04.001

Costa, E., Vendeville, B.C., 2002. Experimental insights on the geometry and kinematics of fold-andthrust belts above weak, viscous evaporitic décollement. Journal of Structural Geology 24, 1729 1739.

Cotton, J.T., Koyi, H.A., 2000. Modeling of thrust fronts above ductile and frictional detachments: application to structures in the Salt Range and Potwar Plateau, Pakistan. Geological Society of America Bulletin 112, 351-363. 
Coward, M., Kim, J., Parke, J., 1980. A correlation of Lewisian structures and their displacement across the lower thrusts of the Moine thrust zone, NW Scotland. Proceedings of the Geologists' Association 91, 327-337.

Cruz, L., Malinski, J., Wilson, A., Take, W.A., Hilley, G., 2010. Erosional control of the kinematics and geometry of fold-and-thrust belts imaged in a physical and numerical sandbox. Journal of Geophysical Research 115. https://doi.org/10.1029/2010JB007472

Dahlen, F.A., 1990. Critical Taper Model of Fold-And-Thrust Belts and Accretionary Wedges. Annual Review of Earth and Planetary Sciences 18, 55-99. https://doi.org/10.1146/annurev.ea.18.050190.000415

DeCelles, P.G., Giles, K.A., 1996. Foreland basin systems. Basin Research 8, 105-123.

Espurt, N., Brusset, S., Baby, P., Hermoza, W., Bolaños, R., Uyen, D., Déramond, J., 2008. Paleozoic structural controls on shortening transfer in the Subandean foreland thrust system, Ene and southern Ucayali basins, Peru: SHORTENING TRANSFER IN THE UCAYALI BASIN. Tectonics 27, n/a-n/a. https://doi.org/10.1029/2007TC002238

Eude, A., Roddaz, M., Brichau, S., Brusset, S., Calderon, Y., Baby, P., Soula, J.-C., 2015. Controls on timing of exhumation and deformation in the northern Peruvian eastern Andean wedge as inferred from low-temperature thermochronology and balanced cross section: exhumation and deformation of north Peru. Tectonics 34, 715-730. https://doi.org/10.1002/2014TC003641

Ferrer, O., Roca, E., Vendeville, B.C., 2014. The role of salt layers in the hangingwall deformation of kinked-planar extensional faults: Insights from 3D analogue models and comparison with the Parentis Basin. Tectonophysics 636, 338-350. https://doi.org/10.1016/j.tecto.2014.09.013

Fillon, C., Huismans, R.S., van der Beek, P., 2013. Syntectonic sedimentation effects on the growth of fold-and-thrust belts. Geology 41, 83-86.

Gil Rodriguez, W., Baby, P., Ballard, J.-F., 2001. Structure et contrôle paléogéographique de la zone subandine péruvienne. Comptes Rendus de l'Académie Des Sciences - Series IIA - Earth and Planetary Science 333, 741-748. https://doi.org/10.1016/S1251-8050(01)01693-7

Gil Rodriguez, W.F.G., 2001. Evolution latérale de la déformation d'un front orogénique: Exemple des bassins subandins entre 0 et 16 S. Université Toulouse III Paul Sabatier (UT3 Paul Sabatier).

Graveleau, F., Malavieille, J., Dominguez, S., 2012. Experimental modelling of orogenic wedges: A review. Tectonophysics 538-540, 1-66. https://doi.org/10.1016/j.tecto.2012.01.027

Grelaud, S., Sassi, W., de Lamotte, D.F., Jaswal, T., Roure, F., 2002. Kinematics of eastern Salt Range and South Potwar Basin (Pakistan): a new scenario. Marine and Petroleum Geology 19, 11271139. https://doi.org/10.1016/S0264-8172(02)00121-6

Hermoza, W., Brusset, S., Baby, P., Gil, W., Roddaz, M., Guerrero, N., Bolaños, R., 2005. The Huallaga foreland basin evolution: Thrust propagation in a deltaic environment, northern Peruvian Andes. Journal of South American Earth Sciences, Cenozoic Andean Basin Evolution 19, 21-34. https://doi.org/10.1016/j.jsames.2004.06.005

Hubbert, M.K., 1951. Mechanical basis for certain familiar geologic structures. Geological Society of America Bulletin 62, 355-372.

Hubbert, M.K., 1937. Theory of scale models as applied to the study of geologic structures. Geological Society of America Bulletin 48, 1459-1520.

Hubbert, M.K., Rubey, W.W., 1959. Role of fluid pressure in mechanics of overthrust faulting I. Mechanics of fluid-filled porous solids and its application to overthrust faulting. Geological Society of America Bulletin 70, 115-166.

Hudec, M.R., Jackson, M.P.A., 2006. Advance of allochthonous salt sheets in passive margins and orogens. AAPG Bulletin 90, 1535-1564. https://doi.org/10.1306/05080605143

Huiqi, L., McClay, K., Powell, D., 1992. Physical models of thrust wedges. Thrust Tectonics. Springer, $71-81$.

Kim, Y.-S., Sanderson, D.J., 2005. The relationship between displacement and length of faults: a review. Earth-Science Reviews 68, 317-334. https://doi.org/10.1016/j.earscirev.2004.06.003 
Kley, J., Monaldi, C.R., Salfity, J.A., 1999. Along-strike segmentation of the Andean foreland: causes and consequences. Tectonophysics 301, 75-94.

Klinkmüller, M., Schreurs, G., Rosenau, M., Kemnitz, H., 2016. Properties of granular analogue model materials: A community wide survey. Special Issue on GeoMod 2014 - Modelling in Geoscience 684, 23-38. https://doi.org/10.1016/j.tecto.2016.01.017

Koyi, H.A., Hessami, K., Teixell, A., 2000. Epicenter distribution and magnitude of earthquakes in foldthrust belts: insights from sandbox models. Geophysical Research Letters 27, 273-276.

Krantz, R.W., 1991. Measurements of friction coefficients and cohesion for faulting and fault reactivation in laboratory models using sand and sand mixtures. Tectonophysics 188, 203-207.

Lacquement, F., Mansy, J.-L., Hanot, F., Meilliez, F., 1999. Retraitement et interprétation d'un profil sismique pétrolier méridien au travers du Massif paléozoïque ardennais (Nord de la France). Comptes Rendus de l'Académie Des Sciences-Series IIA-Earth and Planetary Science 329, 471477.

Lohrmann, J., Kukowski, N., Adam, J., Oncken, O., 2003. The impact of analogue material properties on the geometry, kinematics, and dynamics of convergent sand wedges. Journal of Structural Geology 25, 1691-1711.

Macedo, J., Marshak, S., 1999. Controls on the geometry of fold-thrust belt salients. Geological Society of America Bulletin 111, 1808-1822.

Macellari, C., Hermoza, W., 2009. Subandean segmentation and its impact on hydrocarbon exploration in the Central/Northern Andes. 10th Simposio Bolivariano-Exploracion Petrolera En Las Cuencas Subandinas.

Marshak, S., Wilkerson, M.S., 1992. Effect of overburden thickness on thrust belt geometry and development. Tectonics 11, 560-566.

McClay, K.R., Whitehouse, P.S., 2004. Analog modeling of doubly vergent thrust wedges. AAPG Memoir 82, 184-206.

McGroder, M.F., Lease, R.O., Pearson, D.M., 2015. Along-strike variation in structural styles and hydrocarbon occurrences, Subandean fold-and-thrust belt and inner foreland, Colombia to Argentina. Geological Society of America Memoirs 212, 79-113.

McQuarrie, N., Ehlers, T.A., Barnes, J.B., Meade, B., 2008. Temporal variation in climate and tectonic coupling in the central Andes. Geology 36, 999-1002.

Merle, O., Abidi, N., 1995. Approche expérimentale du fonctionnement des rampes émergentes. Bulletin de La Société Géologique de France 166, 439-450.

Mugnier, J.L., Baby, P., Colletta, B., Vinour, P., Bale, P., Leturmy, P., 1997. Thrust geometry controlled by erosion and sedimentation: A view from analogue models. Geology 25, 427-430.

Nelson, T., 1991. Salt tectonics and listric-normal faulting. The Gulf of Mexico Basin: Geological Society of America, The Geology of North America, v. J 73-89.

Peel, F., Travis, C., Hossack, J., 1995. Genetic structural provinces and salt tectonics of the Cenozoic offshore US Gulf of Mexico: A preliminary analysis.

Ramberg, H., 1981. Gravity, deformation, and the earth's crust: In theory, experiments, and geological application. Academic press.

Ramos, V.A., 2010. The tectonic regime along the Andes: Present-day and Mesozoic regimes. Geological Journal 45, 2-25. https://doi.org/10.1002/gj.1193

Ramos, V.A., Folguera, A., 2009. Andean flat-slab subduction through time. Geological Society, London, Special Publications 327, 31-54. https://doi.org/10.1144/SP327.3

Rowan, M.G., 1995. Structural styles and evolution of allochthonous salt, central Louisiana outer shelf and upper slope.

Rudolf, M., Boutelier, D., Rosenau, M., Schreurs, G., Oncken, O., 2016. Rheological benchmark of silicone oils used for analog modeling of short-and long-term lithospheric deformation. Tectonophysics $684,12-22$. 
Santolaria, P., Vendeville, B.C., Graveleau, F., Soto, R., Casas-Sainz, A., 2015. Double evaporitic décollements: Influence of pinch-out overlapping in experimental thrust wedges. Journal of Structural Geology 76, 35-51. https://doi.org/10.1016/j.jsg.2015.04.002

Schellart, W., 2000. Shear test results for cohesion and friction coefficients for different granular materials: scaling implications for their usage in analogue modelling. Tectonophysics 324, 1-16.

Sellier, N.C., Vendeville, B.C., Loncke, L., 2013. Post-Messinian evolution of the Florence Rise area (Western Cyprus Arc) Part II: Experimental modeling. Basin Dynamics 591, 143-151. https://doi.org/10.1016/j.tecto.2011.07.003

Simpson, G.D., 2006. Modelling interactions between fold-thrust belt deformation, foreland flexure and surface mass transport. Basin Research 18, 125-143.

Smit, J.H.W., Brun, J.-P., Sokoutis, D., 2003. Deformation of brittle-ductile thrust wedges in experiments and nature. Journal of Geophysical Research 108. https://doi.org/10.1029/2002JB002190

Stockmal, G.S., Beaumont, C., Nguyen, M., Lee, B., 2007. Mechanics of thin-skinned fold-and-thrust belts: Insights from numerical models. Geological Society of America Special Papers 433, 63-98.

Storti, F., Marín, R.S., Rossetti, F., Sainz, A.C., 2007. Evolution of experimental thrust wedges accreted from along-strike tapered, silicone-floored multilayers. Journal of the Geological Society 164, 73-85.

Storti, F., McClay, K., 1995. Influence of syntectonic sedimentation on thrust wedges in analogue models. Geology 23, 999-1002.

Suppe, J., 2014. Fluid overpressures and strength of the sedimentary upper crust. Journal of Structural Geology 69, 481-492.

Suppe, J., 2007. Absolute fault and crustal strength from wedge tapers. Geology 35, 1127-1130.

van Keken, P.E., Spiers, C.J., van den Berg, A.P., Muyzert, E.J., 1993. The effective viscosity of rocksalt: implementation of steady-state creep laws in numerical models of salt diapirism. Tectonophysics 225, 457-476. https://doi.org/10.1016/0040-1951(93)90310-G

Wang, X., Suppe, J., Liang, H., He, D., 2014. Large-scale thrusting along the northern margin of the Tibetan Plateau and the southwest Tarim basin: $230 \mathrm{~km}$ long active Hotian thrust sheet. Presented at the EGU General Assembly Conference Abstracts.

Weijermars, R., Jackson, M., Vendeville, B., 1993. Rheological and tectonic modeling of salt provinces. Tectonophysics 217, 143-174.

Weijermars, R., Schmeling, H., 1986. Scaling of Newtonian and non-Newtonian fluid dynamics without inertia for quantitative modelling of rock flow due to gravity (including the concept of rheological similarity). Physics of the Earth and Planetary Interiors 43, 316-330. https://doi.org/10.1016/0031-9201(86)90021-X

Whipple, K.X., 2009. The influence of climate on the tectonic evolution of mountain belts. Nature Geoscience 2, 97-104.

Willett, S., Beaumont, C., Fullsack, P., 1993. Mechanical model for the tectonics of doubly vergent compressional orogens. Geology 21, 371-374.

Wine, G., Vetrici, D., Arcuri, J., Martinez, E., Monges, C., Fernandez, J., Calderon, Y., Galdos, C., 2001. The Huallaga basin and adjacent area, The hydrocarbon potential of NE Peru Huallaga, Santiago and Marañon Basins Study. Proyecto de Asistencia para la Reglamentacion del Sector Energetico del Peru.

Worrall, D., Snelson, S., 1989. Evolution of the northern Gulf of Mexico. The Geology of North America; an Overview: Geological Society of America, v. A 97-138.

Wu, J.E., McClay, K.R., 2011. Two-dimensional analog modeling of fold and thrust belts: dynamic interactions with syncontractional sedimentation and erosion. Thrust Fault-Related Folding AAPG Memoir 94, 301-333.

Wu, S., Bally, A.W., Cramez, C., 1990a. Allochthonous salt, structure and stratigraphy of the northeastern Gulf of Mexico. Part II: Structure. Marine and Petroleum Geology 7, 334-370.

Wu, S., Vail, P.R., Cramez, C., 1990b. Allochthonous salt, structure and stratigraphy of the north-eastern Gulf of Mexico. Part I: Stratigraphy. Marine and Petroleum Geology 7, 318-333. 
Wu, Z., Yin, H., Wang, X., Zhao, B., Jia, D., 2014. Characteristics and deformation mechanism of saltrelated structures in the western Kuqa depression, Tarim basin: Insights from scaled sandbox modeling. Tectonophysics 612-613, 81-96. https://doi.org/10.1016/j.tecto.2013.11.040

Zhou, J., Zhang, B., Xu, Q., 2016. Effects of lateral friction on the structural evolution of fold-and-thrust belts: Insights from sandbox experiments with implications for the origin of landward-vergent thrust wedges in Cascadia. Geological Society of America Bulletin 128, B31320.1. https://doi.org/10.1130/B31320.1

\section{Figure captions}

Figure 1: Topographic map of Peru illustrating the location of the Eastern Cordillera, the Subandean zone, and the main foreland basins of the Subandean zone. The study area (Huallaga Basin) is marked by the red square. Topographic dataset come from NASA SRTM.

Figure 2: Morphostructural map of the Huallaga Basin from seismic interpretation and modified from Gil Rodriguez (2001), Hermoza et al. (2005) and Parsep Internal Report (2001). The location of the seismic lines is indicated by the red lines. Topographic dataset are from NASA SRTM.

Figure 3: Balanced cross section and sequential restorations across the Huallaga and Marañón Basins, from Calderon et al. (2017a).

Figure 4: Interpretation of line 91-mph-23 showing the structure of the Chazuta Thrust hangingwall and footwall in the central part of the basin. The Chazuta Thrust is a faultbend-fold that accommodates a large horizontal displacement (at least $40 \mathrm{~km}$ ). The footwall of this thrust is characterized by folded sedimentary series that seem to branch on a west-verging basement fault under the Chazuta Thrust front. The location of the line is indicated in Figure 2. 
Figure 5: Interpretation of line 91-mph-24 (see location in Figure 2), illustrating the structure of the Chazuta Thrust hangingwall and footwall in the northern part of the basin. The Chazuta Thrust hangingwall is deformed by a backthrust and several small thrusts. High volumes of Permian evaporites (décollement) are incorporated in the hangingwall. The footwall is slightly folded and deformation is poorly imaged.

Figure 6: Interpretation of line 90-mph-02 (see location in Figure 2), illustrating the structure of the Chazuta Thrust hangingwall in the southern part of the basin. The Chazuta Thrust hangingwall is deformed by a pop-up structure. Again, the thick décollement is present in the Chazuta Thrust's hangingwall. To the West, the seismic profile images the eastern part of the fault-propagation fold Biabo Anticline. The structure of the Chazuta Thrust footwall is poorly imaged.

Figure 7: Experimental set up, modified from Santolaria et al. (2015). Deformation of the model was applied by a screw jack pulling the basal sheet. The morphostructural evolution of the model was monitored by two CCD cameras placed in an oblique and an azimuthal position.

Figure 8: Experimental protocol. A) Map-view illustrating the basal boundary conditions for all the models. The basal viscous décollement made of viscous polymer was a $65 \mathrm{~cm}$ long and $60 \mathrm{~cm}$ wide layer. B) and C) initial conditions of the models. The base of the models could be tilted. The thickness of the pre-kinematic tabular sand layers varied from 1.5 to 3 $\mathrm{cm}$. Surface processes were tested by adding pre-kinematic or syn-kinematic wedges having varying thicknesses (Table 2), and by eroding the deformation front. D) Boundary conditions for each model. 
Figure 9: Initial strength profiles of the experimental models.

914 Figure 10: A to E: Morphostructural sequence of the model Chaz_01. "S" stands for the

915 amount of shortening. F) Final cross section (the red dashed line indicates its position in the final top view). The structures are numbered according to their chronological order of their formation. "T" stands for the thrusts and "B" for the backthrusts. In map view, full triangles indicate thrusts, and empty triangle backthrusts. The big grey arrows indicate the direction towards which the basal film was pulled.

Figure 11: A to F) Morphostructural sequence of the model Chaz_02. G) Final cross section (the red dashed line indicates its position on the final top view). On map views, the full lines indicate the active structures, whereas dashed line indicate inactive thrusts. The rest of the legend is the same as in Figure10.

Figure 12: A to F) Morphostructural sequence of the model Chaz_03. G). Final cross section (the red dashed line indicates its position on the final top view). The legend is the same as in Figure10.

Figure 13: A to F) Morphostructural sequence of the model Chaz_04. G) Final cross section (the red dashed line indicates its position on the final top view). The legend is the same as in Figure 10 and 11.

Figure 14: A to F) Morphostructural sequence of the model Chaz_05. G) Final cross section (the red dashed line indicates its position on the final top view). The legend is the same as in Figures 10 and 11. 
Figure 15: A to F) Morphostructural sequence of the model Chaz_06. G) Final cross-section (the red dashed line indicates its position on the final top view). The legend is the same as in Figure 10.

Figure 16: A to F) Morphostructural sequence of the model Chaz_07. G) Final cross section (the red dashed line indicates its position on the final top view). The legend is the same as in Figure10.

\section{Table Caption}

Table 1: Scaling parameters and analogue material properties.

Table 2: Tested parameters. The first models tested the thickness of a flat sedimentary overburden, then the impact of syn-kinematic sedimentation and of tilting the basal slope. In models Chaz_06 and Chaz_07, we combined frontal erosion and pre-kinematic deformation in addition to the previous parameters. "S" stands for the amount of shortening.

Table 3: Initial stress values of the brittle overburden and the viscous décollement for each experimental model.

\section{Supplementary material}

Supplementary material 1: Side-view movie of the Chaz_01 model.

Supplementary material 2: Side-view movie of the Chaz_02 model.

Supplementary material 3: Side-view movie of the Chaz_03 model.

Supplementary material 4: Side-view movie of the Chaz_04 model.

Supplementary material 5: Side-view movie of the Chaz_05 model. 
954 Supplementary material 6: Side-view movie of the Chaz_06 model.

955 Supplementary material 7: Side-view movie of the Chaz_07 model. 


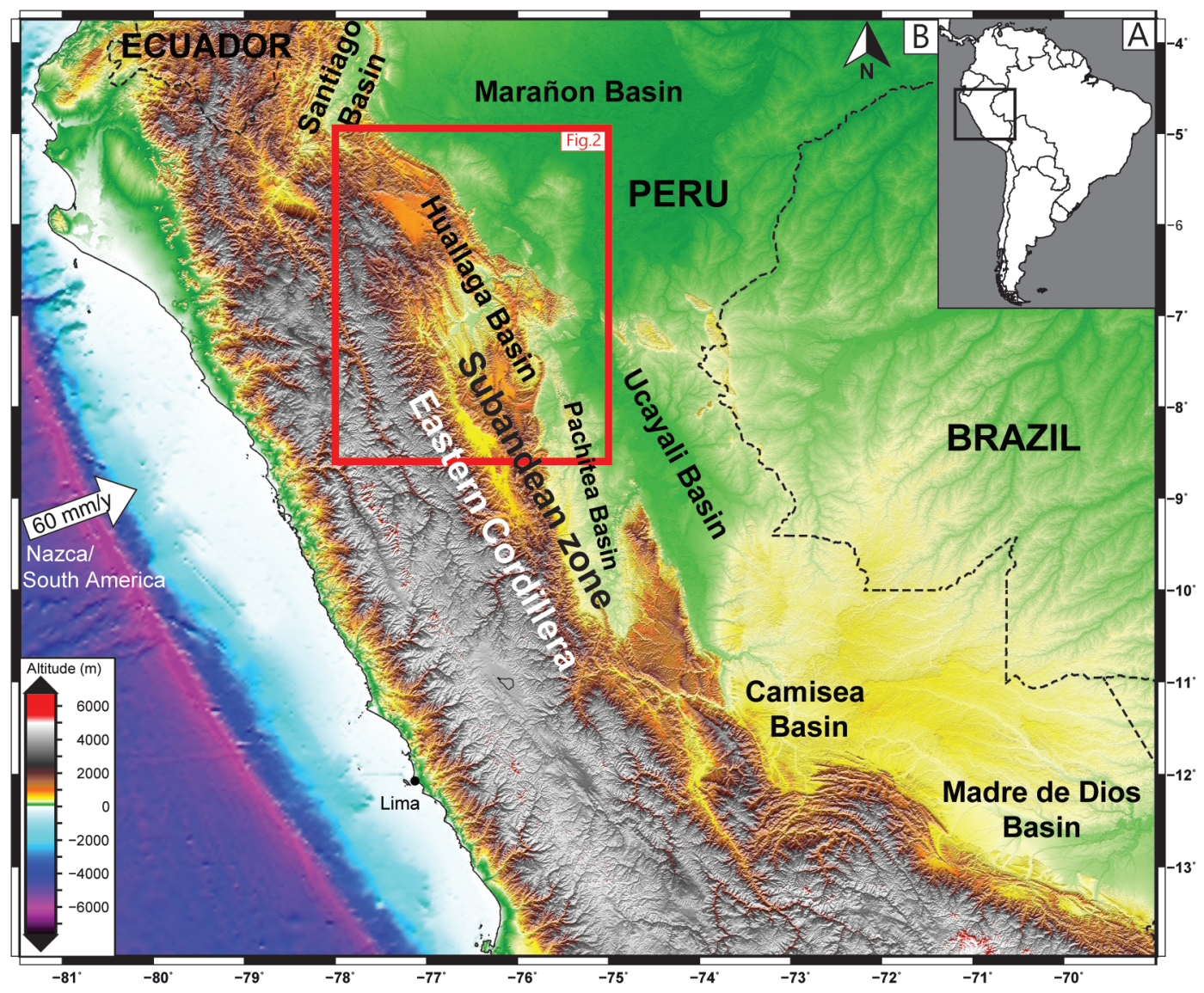

Figure 1: Topographic map of Peru illustrating the location of the Eastern Cordillera, the Subandean zone, and the main foreland basins of the Subandean zone. The study area (Huallaga Basin) is highlighted by the red square. Topographic dataset come from NASA SRTM. 


\begin{tabular}{c|ccc} 
& Huallaga Wedge-top & $\begin{array}{c}\text { Cushabatay } \\
\text { High }\end{array}$ & Marañon Foredeep \\
Eastern Cordillera & Biabo Ant. & Chazuta Thrust
\end{tabular}

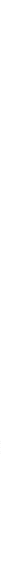

Figure 3: Balanced cross section and sequential restorations across the Huallaga and Marañón Basins, from Calderon et al. (2017a). 


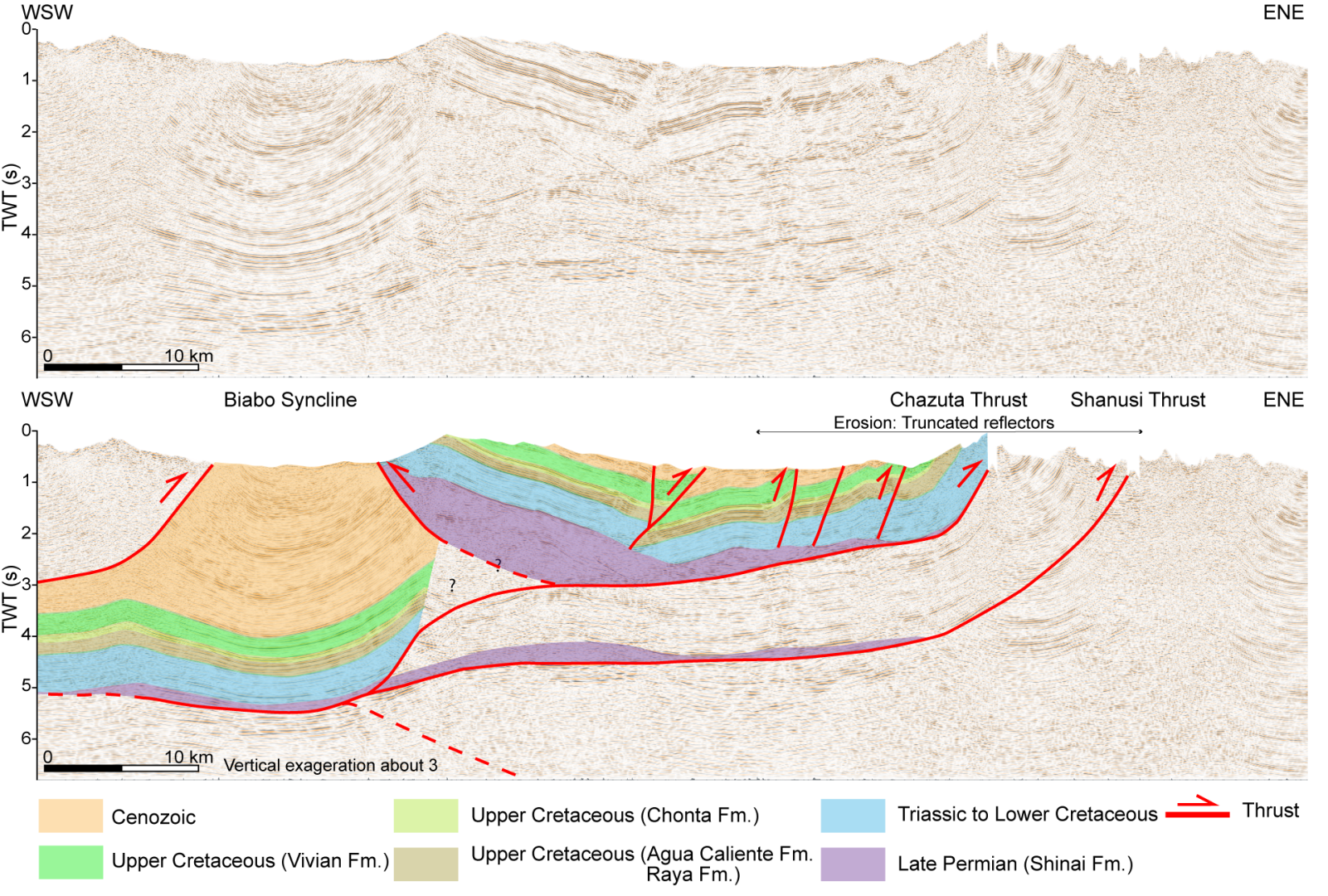

Figure 5: Interpretation of line 91-mph-24 (see location in Figure 2), illustrating the structure of the Chazuta Thrust hangingwall and footwall in the northern part of the basin. The Chazuta Thrust hangingwall is deformed by a backthrust and several small thrusts. High volumes of Permian evaporites (décollement) are incorporated in the hangingwall. The footwall is slightly folded and deformation is poorly imaged. 


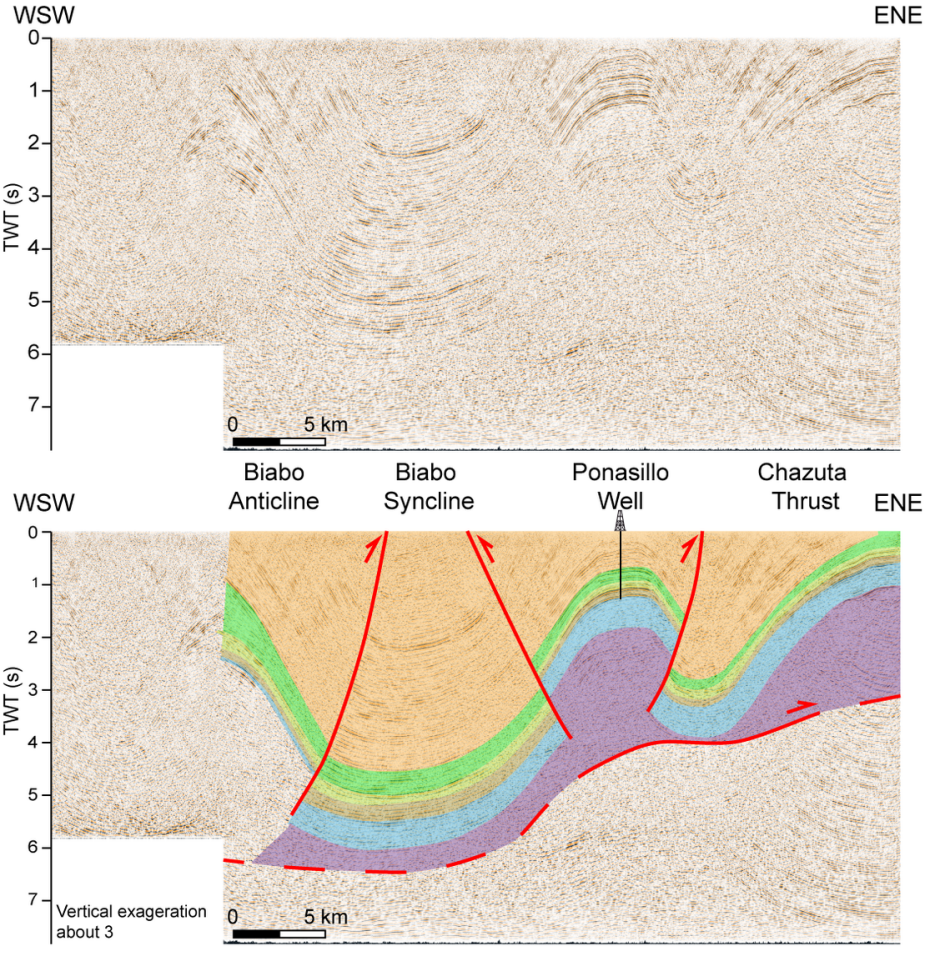

Cenozoic undifferenciated

Upper Cretaceous (Agua Caliente Fm.

Raya Fm.)

Upper Cretaceous (Vivian Fm.) _ Triassic to Lower Cretaceous

Upper Cretaceous (Chonta Fm.) Late Permian (Shinai Fm.)

$\rightarrow$ Thrust

Figure 6: Interpretation of line 90-mph-02 (see location in Figure 2), illustrating the structure of the Chazuta Thrust hangingwall in the southern part of the basin. The Chazuta Thrust hangingwall is deformed by a pop-up structure. Again, the thick décollement is present in the Chazuta's

Thrust hangingwall. To the West, the seismic images the eastern part of the fault-propagation fold Biabo Anticline. The structure of the Chazuta Thrust footwall is poorly imaged. 


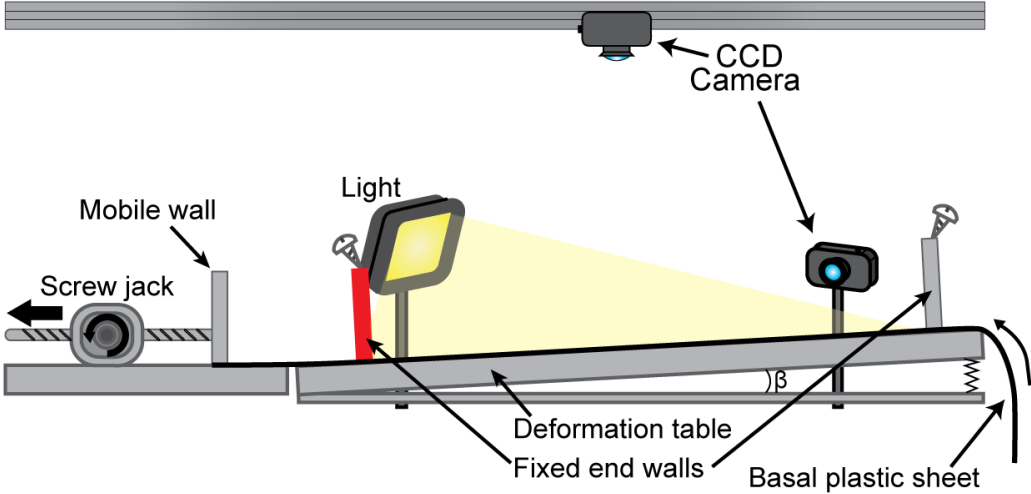

Figure 7: Experimental set-up modified from Santolaria et al. (2015). Deformation of the model was applied by a screw-jack pulling the basal sheet. The morphostructural evolution of the model was monitored by two CCD cameras placed in an oblique and in an azimuthal position. 
Silicone pinch-out

$B$

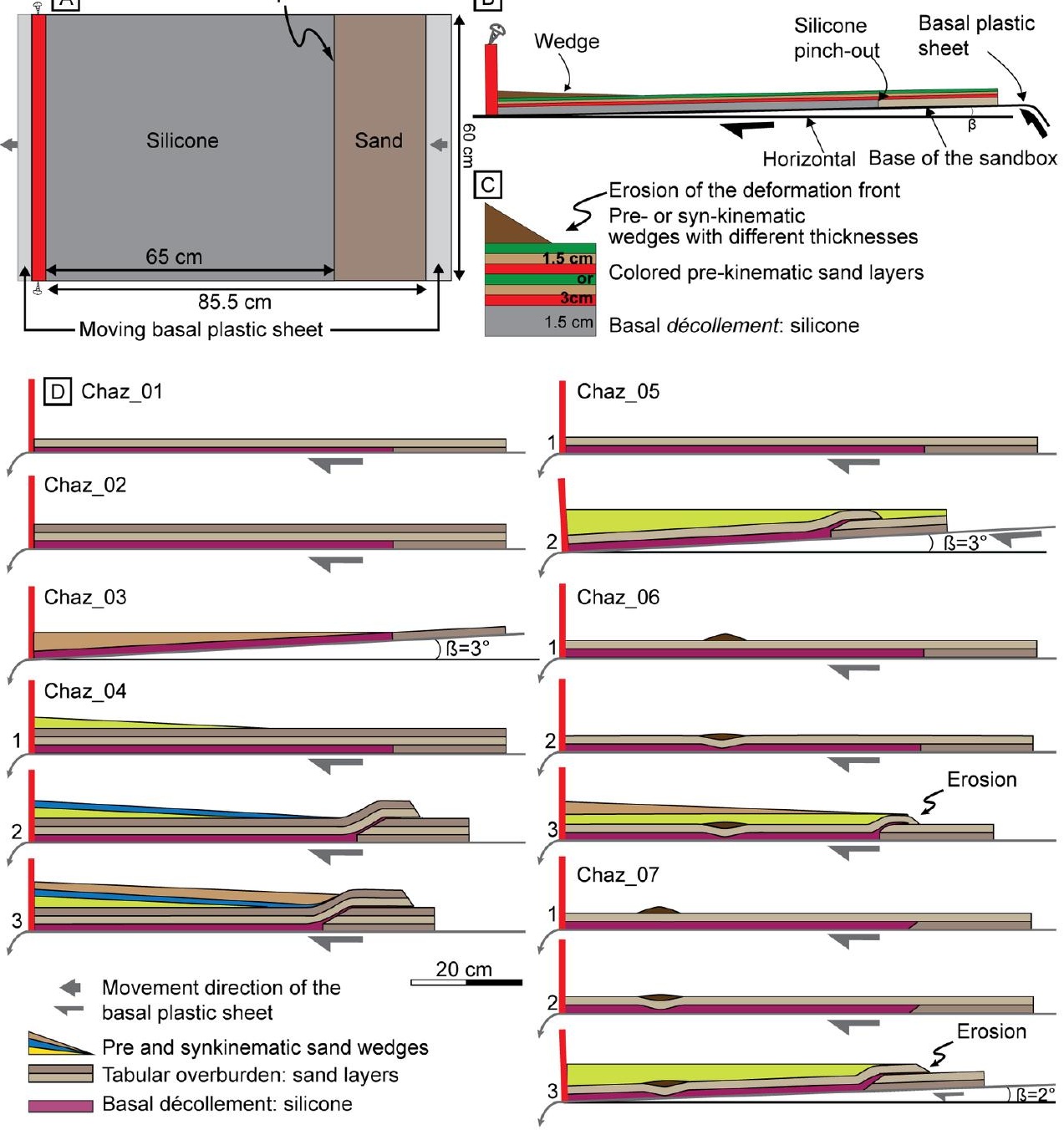

Figure 8: Experimental protocol. A) Map-view illustrating the basal boundary conditions for all the models. The basal viscous décollement was a $65 \mathrm{~cm}$ long and $60 \mathrm{~cm}$ wide layer of viscous polymer. B) and C) initial conditions of the models. The base of the models could be tilted. The thickness of the pre-kinematic tabular sand layers varied from 1.5 to $3 \mathrm{~cm}$. Surface processes were tested by adding pre-kinematic or syn-kinematic wedges having different thicknesses (Table 1), and by eroding the deformation front. D) Boundary conditions of each model. 
Chaz_01

Chaz_02

Chaz_03

1000

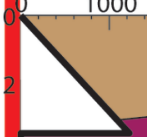

6

\section{Chaz_05}
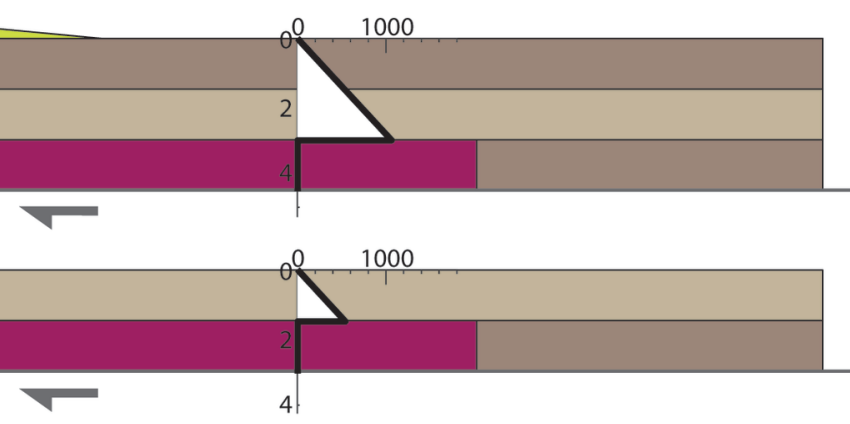

Chaz_06 \& Chaz_07 01000
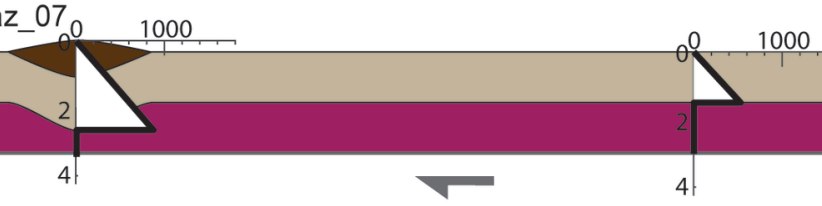

- Movement direction of the basal plastic sheet

Pre and synkinematic sand wedges

Tabular overburden: sand layers

Basal décollement: silicone

Figure 9: Initial strength profiles of the experimental models. 


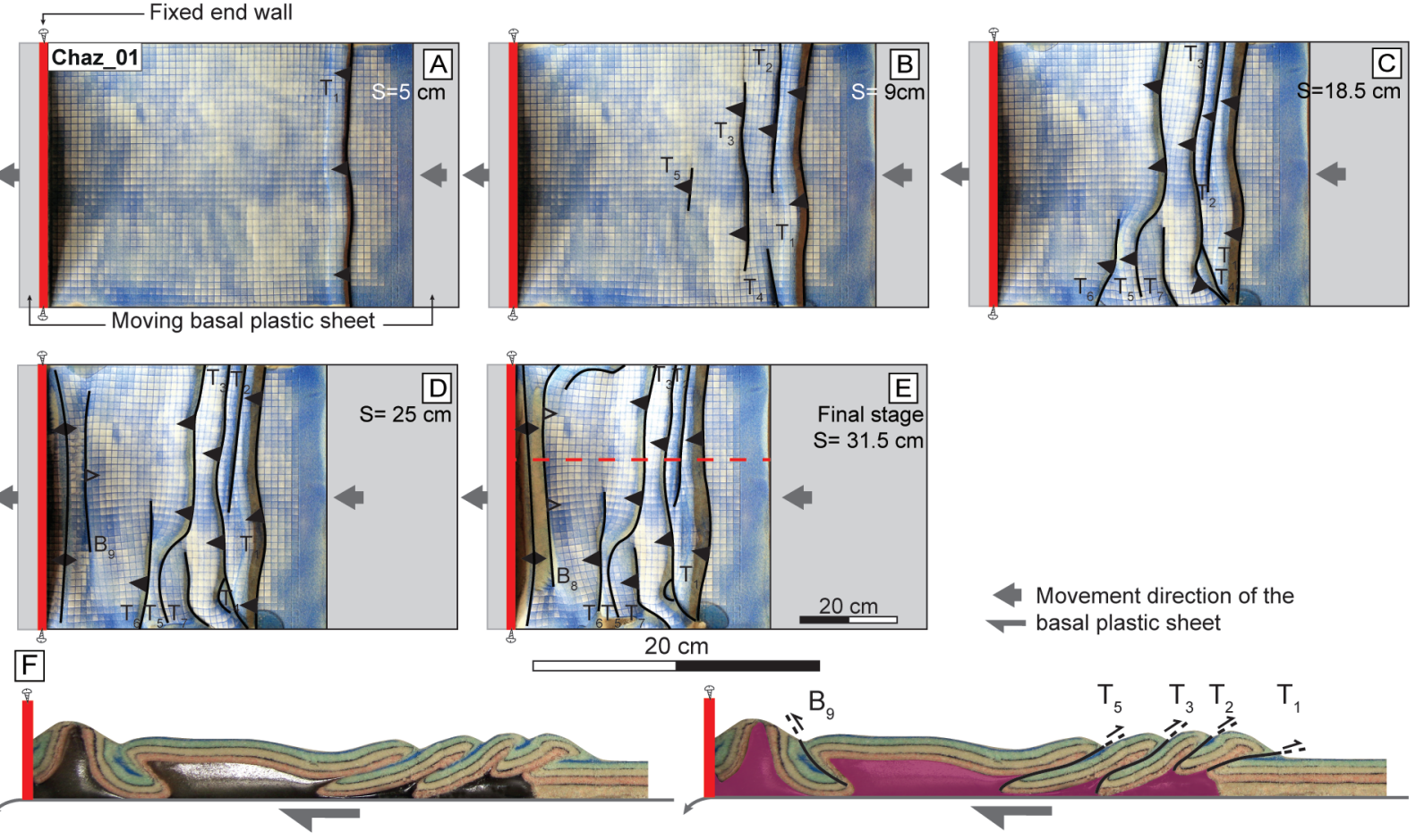

Figure 10: A to E: Morphostructural sequence of the Chaz_01 model. "S" stands for the amount of shortening. F) Final cross section (the red dashed line indicates its position in the final top view). The structures are numbered according to their chronological order of their formation. "T" stands for the thrusts and "B" for the backthrusts. In map view, full triangles indicate thrusts, and empty triangle backthrusts. The big grey arrows indicate the direction towards which the basal film was pulled. 


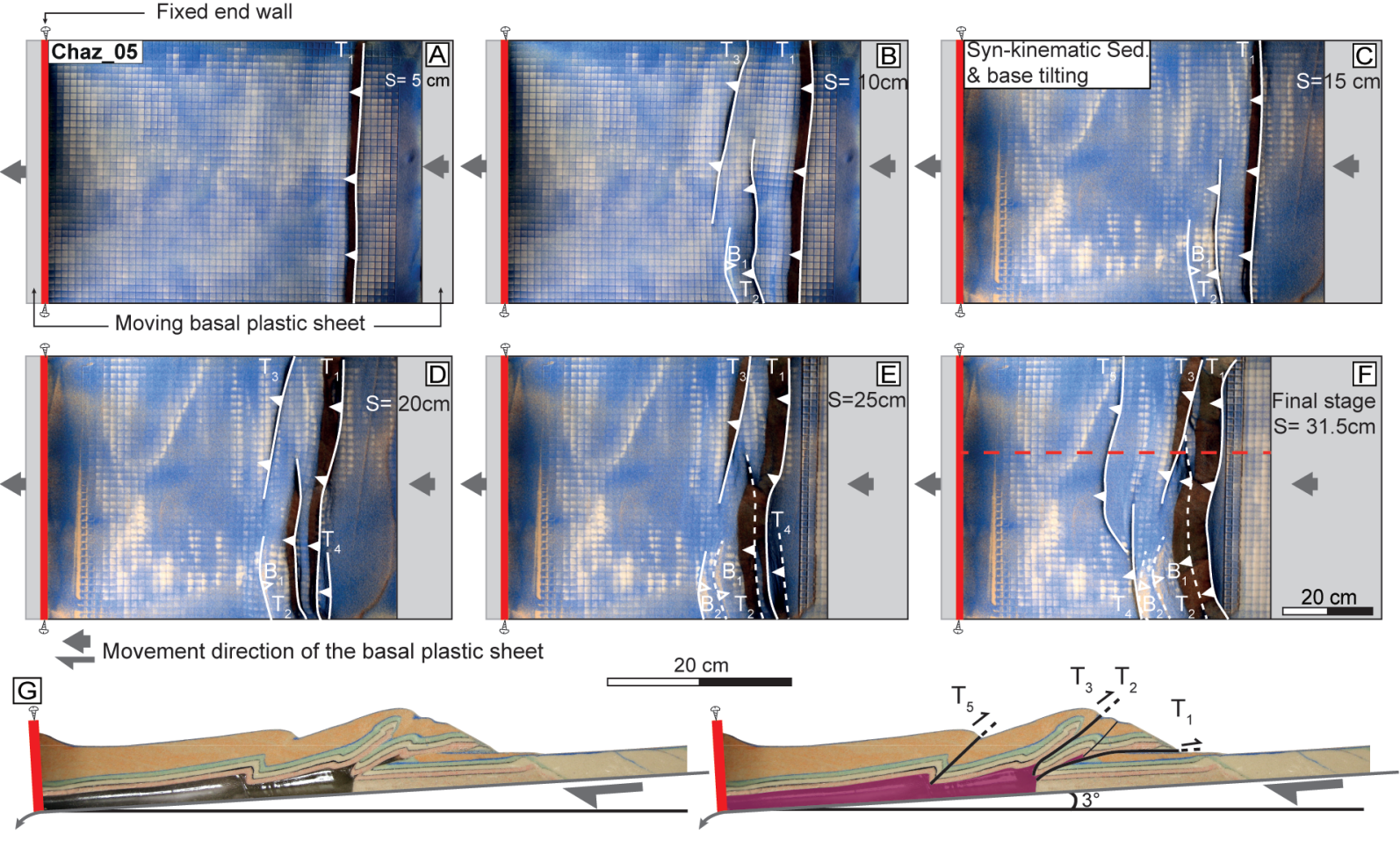

Figure 14: A to F) Morphostructural sequence of the Chaz_05 model. G) Final cross section (the red dashed line indicates its position on the final top view). The legend is the same as in Figures 9 and 10. 
$\varlimsup_{\infty}$ Fixed end wall
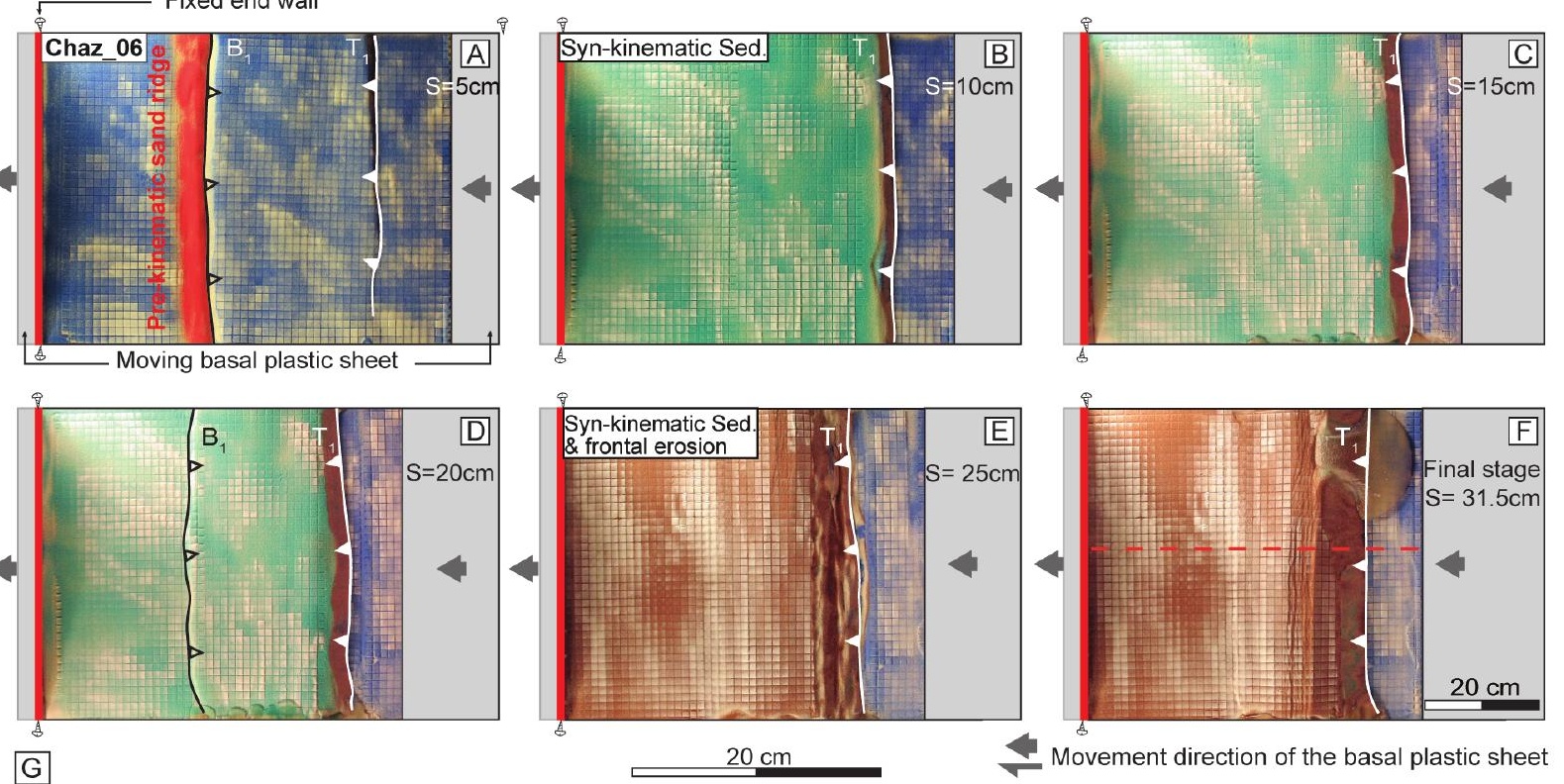

$\mathrm{G}$

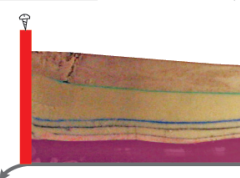

Movement direction of the basal plastic sheet
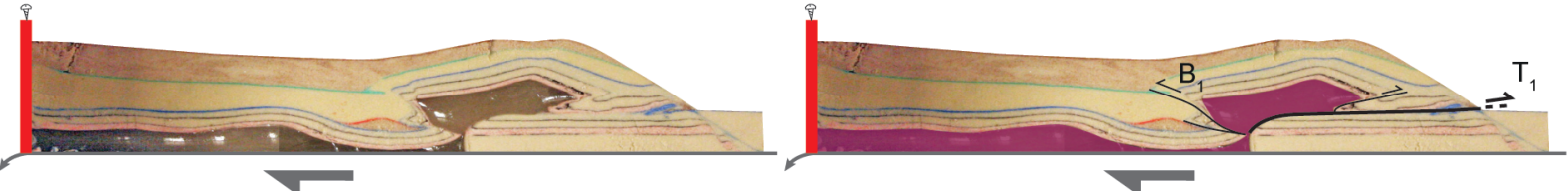

Figure 15: A to F) Morphostructural sequence of the Chaz_06 model. G) Final cross-section (the red dashed line indicates its position on the final top view). The legend is the same as in Figure 9. 


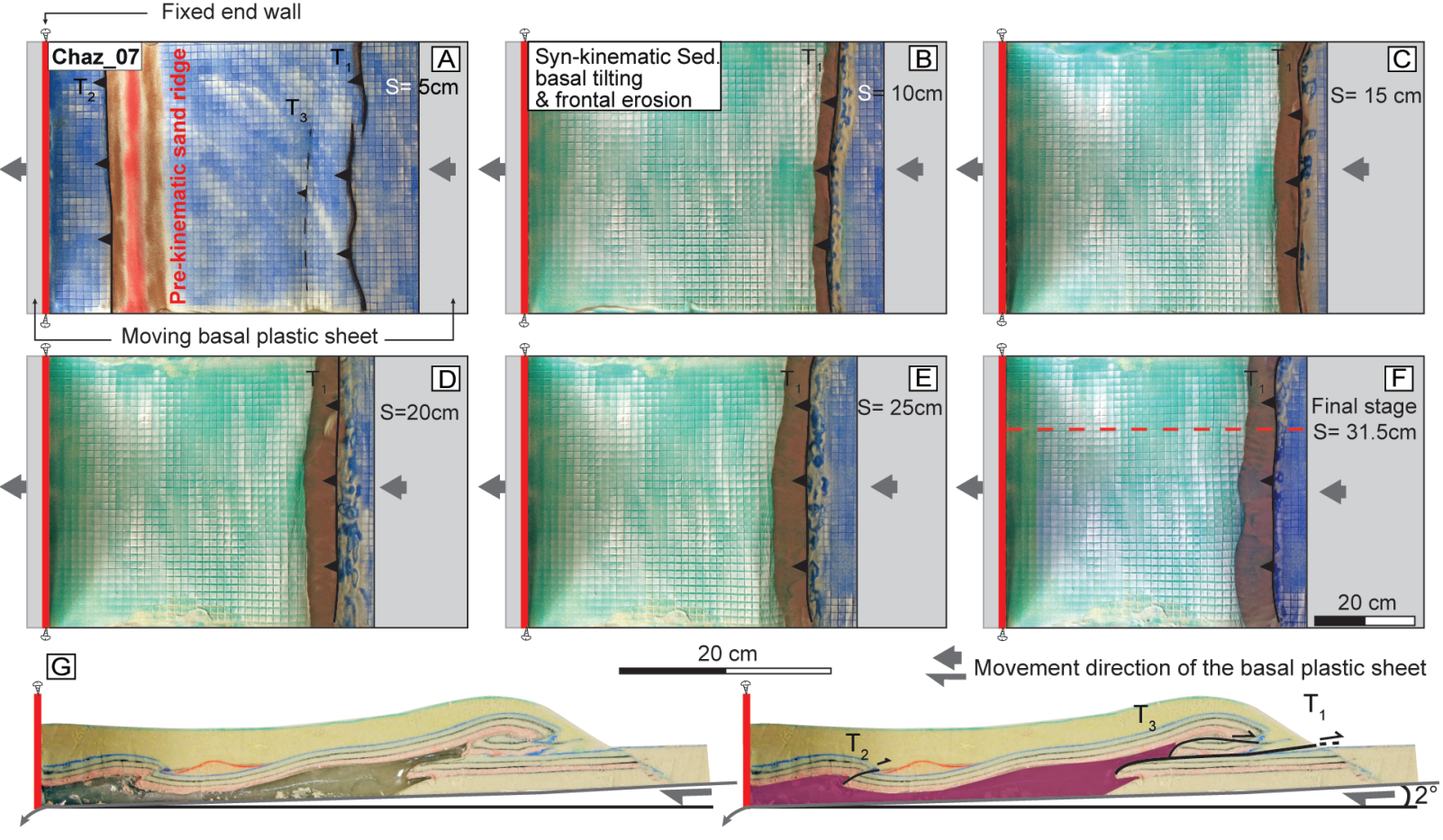

Figure 16: A to F) Morphostructural sequence of the Chaz_07 model. G) Final cross section (the red dashed line indicates its position on the final top view). The legend is the same as in Figure 9. 


\begin{tabular}{|c|c|c|c|}
\hline Parameter & Model & Nature & Model to Nature ratio \\
\hline Length, L (m) & 0.01 & 1500 & $0.66 \times 10^{-5}$ \\
\hline Gravity, g $\left(\mathrm{m} . \mathrm{s}^{-2}\right)$ & 9.81 & 9.81 & 1 \\
\hline \multicolumn{4}{|l|}{ Brittle overburden GA39 dry sand } \\
\hline Density, $\rho\left(\mathrm{g} \cdot \mathrm{cm}^{-3}\right)$ & 1.4 & 2.6 & 0.54 \\
\hline Cohesion, $\mathrm{c}(\mathrm{Pa})$ & $\approx 40$ & $10-30 \times 10^{6}$ & $\approx 1.3 \times 10^{-6}$ \\
\hline Internal friction coefficient, $\mu$ & $\approx 0.7$ & $0.6-0.85$ & \\
\hline \multicolumn{4}{|l|}{ Brittle overburden NE34 dry sand } \\
\hline Density, $\rho\left(\mathrm{g} . \mathrm{cm}^{-3}\right)$ & 1.6 & 2.6 & 0.62 \\
\hline Cohesion, $\mathrm{c}(\mathrm{Pa})$ & $\approx 60$ & $10-30 \times 10^{6}$ & $\approx 2 \times 10^{-6}$ \\
\hline Internal friction coefficient, $\mu$ & $\approx 0.6$ & $0.6-0.85$ & \\
\hline \multicolumn{4}{|l|}{ Viscous décollement } \\
\hline Density, $\rho$ (g.cm-3) & 0.965 & 2.2 & 0.44 \\
\hline Viscosity, $\eta$ (Pa.s) & $2.2 \times 10^{4}$ & $5 \times 10^{18}$ & $4.4 \times 10^{-15}$ \\
\hline Stress, $\sigma=\rho \times \mathrm{g} \times \mathrm{L}(\mathrm{Pa})$ & & & $3.33 \times 10^{-6}$ \\
\hline Strain rate, $\varepsilon=\sigma / \eta\left(\mathrm{s}^{-1}\right)$ & & & $7.5 \times 10^{8}$ \\
\hline \multirow[t]{2}{*}{ Time, $t=1 / \varepsilon(s)$} & 3600 & $2.7 \times 10^{12}(85000 \mathrm{y})$ & $1.33 \times 10^{-9}$ \\
\hline & $65 \mathrm{~h}$ & $5.6 \mathrm{My}$ & \\
\hline Shortening rate, $v=\varepsilon \times L$ & $5 \mathrm{~mm} / \mathrm{h}$ & $9 \mathrm{~mm} / \mathrm{yr}$ & 4950 \\
\hline
\end{tabular}

Table 1: Scaling parameters and analogue material properties. 


\begin{tabular}{|c|c|c|c|c|c|c|c|}
\hline Model \# & Chaz_01 & Chaz_02 & Chaz_03 & Chaz_04 & Chaz_05 & Chaz_06 & Chaz_07 \\
\hline Sidewalls lubrication & Yes & Yes & None & Yes & None & Yes & Yes \\
\hline Décollement thickness (cm) & 1 & 1.5 & 1.5 & 1.5 & 1.5 & 1.5 & 1.5 \\
\hline $\begin{array}{l}\text { Tabular overburden } \\
\text { thickness }(\mathrm{cm})\end{array}$ & 1.5 & 3 & 0 & 3 & 1.5 & 1.5 & 1.5 \\
\hline $\begin{array}{l}\text { Prekinematic wedge } \\
\text { maximum thickness }(\mathrm{cm})\end{array}$ & None & None & 3.5 & 2 & None & None & None \\
\hline $\begin{array}{l}\text { Synkinematic wedge - number } \\
\text { and maximum thickness }(\mathrm{cm})\end{array}$ & None & None & None & $\begin{array}{c}1-1.2 \\
2-3\end{array}$ & $1-4$ & $\begin{array}{l}1-4 \\
2-3\end{array}$ & $1-3.3$ \\
\hline Décollement dip $(\beta)$ & 0 & 0 & $3^{\circ}$ prekinematic & 0 & $3^{\circ}$ at $\mathrm{S}=10 \mathrm{~cm}$ & 0 & $2^{\circ}$ at $S=7.5 \mathrm{~cm}$ \\
\hline $\begin{array}{l}\text { Prekinematic deformation: } \\
\text { early syncline }\end{array}$ & None & None & None & None & None & $\begin{array}{l}\text { at } 28 \mathrm{~cm} \text { from the } \\
\text { western backstop }\end{array}$ & $\begin{array}{l}\text { at } 18 \mathrm{~cm} \text { from the } \\
\text { western backstop }\end{array}$ \\
\hline Frontal erosion & None & None & None & None & None & at $S=21 \mathrm{~cm}$ & $\begin{array}{l}\text { During the whole } \\
\text { shortening }\end{array}$ \\
\hline
\end{tabular}

Table 2: Tested parameters. The first models tested the thickness of a flat sedimentary overburden, then the impact of syn-kinematic sedimentation and of tilting the basal slope. In models Chaz_06 and Chaz_07, we combined frontal erosion and pre-kinematic deformation in addition to the previous parameters. "S" stands for the amount of shortening. 


\begin{tabular}{lccccc} 
Model \# & $\sigma_{v}\left(=\sigma_{3}\right)(P a)$ & $\sigma_{1}(\mathrm{~Pa})$ & $\sigma_{1}-\sigma_{3}(\mathrm{~Pa})$ & $\tau_{d}(\mathrm{~Pa})$ & $R=\sigma_{1}-\sigma_{3} / \tau_{d}$ \\
\hline \hline Chaz_01 & 221 & 749 & 529 & 3 & 173 \\
\hline Chaz_02 & 441 & 1499 & 1057 & 2 & 519 \\
\hline Chaz_03 max (backstop) & 515 & 1749 & 1234 & 2 & 606 \\
\hline Chaz_03 min (wedge toe) & 74 & 250 & 176 & 2 & 87 \\
\hline Chaz_04 max (backstop) & 736 & 2498 & 1762 & 2 & 865 \\
\hline Chaz_04 min (wedge toe) & 441 & 1499 & 1057 & 2 & 519 \\
\hline Chaz_05 & 221 & 749 & 529 & 2 & 260 \\
\hline Chaz_06 max (flat overburden + subsided ridge) & 368 & 1249 & 881 & 4 & 216 \\
\hline Chaz_06 min (flat overburden) & 221 & 749 & 529 & 2 & 260 \\
\hline Chaz_07 max (flat overburden + subsided ridge) & 368 & 1249 & 881 & 4 & 216 \\
\hline Chaz_07 min (flat overburden) & 221 & 749 & 529 & 2 & 260 \\
\hline
\end{tabular}

Table 3: Initial stress values of the brittle overburden and the viscous décollement for each experimental model. 